Revista de Estudios Histórico-Jurídicos

[Sección historia de las instituciones]

XL (Valparaíso, Chile, 2018)

[pp. 645-673]

\title{
LA MARCA COMO PENA EN EL DERECHO HISTÓRICO ESPAÑOL: CONSIDERACIONES SOBRE SU NATURALEZA JURÍDICA
}

\author{
[Branding as Punishment in the History of Spanish Law: Considerations on Its \\ Legal Nature]
}

\author{
Patricia Zambrana Moral* \\ Universidad de Málaga, España
}

\begin{abstract}
RESUMEN
Partiendo de la crueldad del derecho penal histórico y de su tipología punitiva, nos detenemos en analizar la pena de marca, bastante frecuente y poco estudiada. El objetivo es concretar sus características y modalidades y determinar su naturaleza jurídica como pena corporal o infamante tras conceptualizar ambas categorías ante la falta de unanimidad de la doctrina al respecto. Seguidamente, examinamos la presencia concreta de esta pena, prestando especial atención a la decalvatio visigoda, en una selección de normas del Derecho histórico español medieval (Liber Indiciorum, Fuero Juzgo, Costums de Tortosa, Fuero Real, Siete Partidas...), y la evolución en la Edad Moderna hasta su abolición definitiva.
\end{abstract}

\section{Palabras clave}

Pena de marca - Penas infamantes Penas corporales - Infamia - Decalvatio.

\begin{abstract}
This work analyzes the cruelty of the history of criminal law and its punitive nature, especially the punishment of branding which was frequently applied and there has been not much research about it. The aim of this study is to understand the characteristics of this punishment and how it was applied, as well as to determine the legal grounds for its practice as corporal or infamous punishment, then conceptualizing both categories since there is no agreement in the doctrine regarding this matter. We will then examine the effective use of this punishment by paying especial attention to the Visigoth decalvatio, mentioned in a selection of norms of the Medieval Spanish historical law (Liber Iudiciorum, Fuero Juzgo, Costums de Tortosa, Royal Fuero, Seven-Part Code...), and the evolution in the Modern Times until its final abolition.

\section{KeYwordS}

Branding as punishment - Infamous punishment - Corporal punishment Infamy - Decalvatio.
\end{abstract}

RECiBIDO el 25 de abril de 2018 y ACEPTADO el 30 de julio de 2018

* Profesora titular de Historia del Derecho y de las Instituciones, Facultad de Derecho, Universidad de Málaga. Dirección: Boulevard Louis Pasteur, Campus de Teatinos, 29010 Málaga, España. E-mail: pzambrana@uma.es 


\section{INTRODUCCIÓN}

Una de las principales características del Derecho penal histórico es la crueldad en la tipología punitiva y en su ejecución. En dicho ámbito, y sin ser ajena a dicha crueldad, se situaría la imposición de marcas a los delincuentes, bastante frecuente en la historia ${ }^{1}$ pese a la escasa atención que la doctrina ha prestado a esta sanción, tal vez por la dificultad de deslindarla de otras penas corporales como la mutilación ${ }^{2}$. Se podría decir que todas las mutilaciones son marcas o funcionan como tales, pero no todas las marcas son mutilaciones. Se ha definido la marca como la impresión de "una señal indeleble, generalmente una letra, en cierta parte del cuerpo del culpable, por medio de un hierro ardiente", siendo una medida que ya utilizaban los romanos para los calumniadores y que se mantiene en otros ordenamientos jurídicos ${ }^{3}$. Solía tener un carácter perpetuo; se aplicaba en la frente, "afeitando primero la cabeza y las cejas" "y el que era condenado a trabajos forzosos la sufría en la espalda o en la cara ${ }^{5}$. En la época del Principado, se castigaba con la marca al que presentaba de mala fe una demanda falsa ${ }^{6}$. En Atenas, la marca se imponía "a los esclavos fugitivos y a los desertores y aunque más parecía una señal que un padrón de ignominia, a veces se aplicaba a grandes

${ }^{1}$ A la h a b i t u a 1 i d a d de las marcas aludía Sainz Guerra, de modo que "no solo las mutilaciones o los azotes servían como marca", sino que, a veces, se condenaba al reo "a ser señalado en su cuerpo [...] con un hierro candente”. SAINZ GUERRA, Juan, La evolución del derecho penal en España (Jaén, Universidad de Jaén, 2004), p. 294. Las marcas ya estaban presentes en el Código de Hammurabi. Ver Código de Hammurabi, $\$ 127$ (ed. de Lara Peinado, Federico, (Madrid, Editora Nacional, 1982; 4a ed., Madrid, Tecnos, 2008), p. 105. Asimismo, el primitivo derecho penal chino imponía marcas incluso para delitos que no revestían especial gravedad. Jiménez de Asúa, Luis, Tratado de Derecho Penal (4a ed., Buenos Aires, Losada, 1964), I, pp. 268-269.

${ }^{2}$ La mutilación tenía como finalidad "la intimidación, la imposibilidad de ejecutar nuevos delitos y la facilidad de apreciar la reincidencia o la reiteración”, es decir, se trataba de dejar "una huella física permanente" y, por este motivo, en muchas ocasiones, además de pena funcionaba como marca como sucedía con la "decalvatio goda que se transmite por el Fuero Juzgo". LALINDE ABADía, Jesús, Las culturas represivas de la humanidad (H. 1945) (Zaragoza, Universidad de Zaragoza, 1992), II, pp. 825 y 830.

3 García Goyena, Florencio y Aguirre, Joaquín, Febrero, o librería de jueces, abogados y escribanos, comprensiva de los Códigos civil, penal y administrativo, tanto en la parte teórica como en la práctica con arreglo en un todo a la legislación hoy vigente... (2a ed. corregida y anotada por los doctores Aguirre, Joaquín y Montalbán, Manuel, Madrid, Imprenta y Librería de Don Ignacio Boix, 1845), III, p. 102. Comenta las ediciones de esta obra GIBERT Y SÁNCHEZ DE LA Vega, Rafael, Recensión de Bicentenario de la muerte de don José Febrero. Acto de homenaje y catálogo de la exposición bibliográfica, Consejo General del Notariado, Madrid, 1991, en AHDE., 68 (1998), p. 594.

4 Gutiérrez Fernández, Benito, Examen histórico del derecho penal (Madrid, Antonio Peñuelas, 1866), p. 50.

${ }^{5}$ SAINZ Guerra, Juan, cit. (n. 1), p. 294. Sin embargo, se acabó prohibiendo que las marcas se hicieran en la cara porque era reflejo de la divinidad, obligándose a que "los condenados a minas fueran marcados en manos o pantorrillas”. Véase C. 9, 47, 17.

${ }^{6}$ Cfr. Mommsen, Theodor, Römisches Strafrecht (trad. castellana de Dorado MonTero, Pedro, Bogotá, Temis, 1991; Pamplona, 1999), pp. 605-606. 


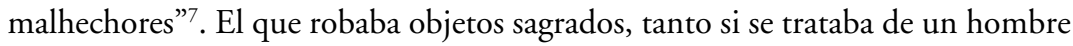
libre como de un esclavo, era expulsado desnudo del territorio tras ser azotado y marcado en la frente y en las manos con el sello de su delito ${ }^{8}$. Los espartanos establecían penas tan crueles que el condenado prefería el suicidio y entre ellas se encontraban la infamia, heridas, tatuajes con fuego o coronamiento?

Normalmente, aunque no siempre, el reo era marcado en una parte visible del cuerpo ${ }^{10}$. Así, como veremos, los visigodos cortaban el cabello y lesionaban el cuero cabelludo y la frente. En otras ocasiones, la marca guardaba relación con el delito cometido (por ejemplo, la letra "L" para los ladrones y la "B" para los blasfemos) con lo que se permitía identificar al delincuente y conocer su reincidencia con una finalidad práctica y se perpetuaba "el recuerdo del primer castigo" ${ }^{11}$. En el Antiguo Régimen francés, los azotes se acompañaban de una marca que solía hacerse en el hombro y podía ser una flor de lis o las iniciales del delito o de "la pena principal" a la que se había condenado (GAL, si se trataba de la pena de galeras, o $\mathrm{V}$, de $v o l$, robo en francés) ${ }^{12}$.

En cualquier caso, el sujeto marcado quedaba estigmatizado ante la sociedad ${ }^{13}$. Del mismo modo, todas las penas corporales, así como la pena capital tenían un carácter "ejemplarizante" ya que no perseguían solo el dolor, sino también "un halo de infamia que a veces trascendía al propio cadáver y a su familia" ${ }^{14}$. Al infligir tanto las mutilaciones como las marcas corporales, el cuerpo humano deja de ser considerado en su individualidad adquiriendo una trascendencia social como susceptible de ser corregido, y su ejecución pública implicaba el reconocimiento del delito y de la sanción que la comunidad aplicaba a través de los encargados de velar por la misma ${ }^{15}$. Junto a la mutilación, la marca era una pena indeleble al producir en el cuerpo un efecto permanente ${ }^{16}$. La doctrina de finales del siglo

7 Gutiérrez Fernández, Benito, cit. (n. 4), p. 27.

${ }^{8}$ Platón, Las Leyes, Libro IX (Obras Completas, ed. de De Azcárate, Patricio, Madrid, 1872), X.

${ }^{9}$ Gudín Rodríguez-Magariños, Faustino y Nistal Burón, Javier, La historia de las penas. "De Hammurabi a la cárcel electrónica" (Valencia, Tirant lo Blanch, 2015), p. 37. Más tarde, en la sociedad feudal no había "un soporte institucional" para "imponer un sistema de castigos permanentes" y por ello estos solían ser "cortos, severos y fugaces", incluyéndose la marca entre los mismos sin ningún tipo de criterio clasificatorio (pp. 46-47).

${ }^{10}$ Sainz Guerra, Juan, cit. (n. 1), p. 294.

${ }^{11}$ Oliver, Bienvenido, Historia del derecho en Cataluña, Mallorca y Valencia. Código de las Costumbres de Tortosa (Madrid, Imprenta de Miguel Ginesta, 1879), III, p. 351.

${ }^{12}$ Cañizares Navarro, Juan B., Las penas infamantes en las postrimerías del Antiguo Régimen francés: tratamiento normativo y doctrinal, en Foro, Nueva época, 17 (2014), 1, pp. 123 y 126.

${ }^{13}$ La RAE define la palabra e $s \mathrm{t}$ i g m a en su cuarta acepción como la "marca impuesta con hierro candente, bien como pena infamante, bien como signo de esclavitud" y procede etimológicamente del latín stigma ("marca hecha en la piel con un hierro candente", "nota infamante") y del griego $\sigma \tau i ́ \gamma \mu \alpha$.

${ }^{14}$ Gudín Rodríguez-Magariños, Faustino y Nistal Burón, Javier, cit. (n. 9), p. 47.

${ }_{15}$ Redondo, Augustin, Mutilations et marques corporelles dinfamie dans la Castille du $X V I^{e}$ siècle, en Le corps dans la société espagnole des XVI et XVII siècles (Paris, Publications de la Sorbonne, 1990), p. 186.

${ }^{16}$ Ferrer y VAlls, Francisco, Principios de legislación y de codificación extractados de la obra del filósofo inglés Jeremias Bentham (Madrid, Imprenta de Tomas Jordan, 1834), III, pp. 35-36. 
XVIII correspondiente al derecho penal ilustrado estableció una equiparación entre los diferentes tipos de marcas (desollar la frente, imprimir hierros ardiendo en la cara o en otra parte del cuerpo, clavar la lengua o la mano...) y las mutilaciones considerándolas "igualmente inhumanas" 17 .

\section{Naturaleza JuRÍdicA DE LA PENA DE MARCA}

\section{Aspectos conceptuales. Distinción entre penas corporales y penas infamantes}

No tenemos ninguna duda de que cuando hablamos de la marca nos encontramos ante una pena; sin embargo, no hay unanimidad en la doctrina al clasificarla y por tanto a la hora de determinar su auténtica naturaleza. Nuestro propósito sería dilucidar si se trata de una pena corporal o de una pena infamante en sentido estricto y ello con independencia de las evidentes consecuencias infamantes, es decir sobre el honor del condenado, de cualquier pena y del evidente daño físico ocasionado con la marca, sobre todo con algunas de ellas. Tampoco es unánime la doctrina ni la legislación al clasificar las penas en su consideración histórica y no resulta fácil concretar qué debe entenderse por pena corporal y por pena infamante hasta el punto de aparecer, en ocasiones, como un mismo tipo de sanción ${ }^{18}$. Así, "los juristas crearon categorías de penas" según la finalidad única o principal perseguida con su imposición y ejecución", y cada categoría "recibió un nombre"19.

Por este motivo, el primer paso sería determinar cuál es el concepto que vamos a seguir de pena corporal y de pena infamante en base a su finalidad para, a continuación, ubicar la marca en una u otra categoría. No es la primera vez que aventuramos una definición de pena corporal. En trabajos previos y partiendo de

Las explica en pp. 44-46. Se tipifica como pena aflictiva indeleble, en Dumont, Esteban, Tratados de legislación civil y penal, obra extractada de los manuscritos del señor Jeremias Bentham (trad. castellana con comentarios de SALAS, Ramón, con arreglo a la segunda edición revista, corregida y aumentada, Madrid, Imprenta de D. Fermín Villalpando, 1822), III, p. 59.

${ }^{17}$ Lardizábal advierte un fin talional en estas penas (sobre todo las de mutilación): el reo sufría el castigo en la misma parte del cuerpo que le sirvió de instrumento para delinquir (al blasfemo se le cortaba la lengua, al falsario la mano, el sodomita era castrado...). Rechaza tanto las marcas como las restantes sanciones corporales porque eran "crueles por naturaleza", "perniciosas a la república" y con ellas solo se lograba hacer deformes a los hombres, en lugar de corregirlos, careciendo de utilidad porque no permitían alcanzar los fines de la pena. DE LARDIZÁBAL y URIBE, Manuel, Discurso sobre las penas, contraído a las leyes penales de España para facilitar su reforma (Madrid, Joachin Ibarra, Impresor de la Cámara de S. M., 1782, edición con "Introducción" de Serrano ButragueÑo, Ignacio, Granada, Comares, 1997), pp. 91-93. También se opone a la marca impresa, tanto en lugares visibles como no visibles, GuTiérREZ, José Marcos, Discurso sobre los delitos y las penas, en Práctica criminal de España (Madrid, 1804; $2^{a}$ ed., Madrid, Imprenta de D. Fermín Villalpando, 1819), III, pp. 116-118. Indica que, en caso de no abolirse, tenía que combinarse con la muerte o la esclavitud perpetua para evitar la fuga del condenado y no debía acumularse con otra pena que la hiciera "inútil y cruel sin necesidad" (p. 118). Cfr. DumonT, Esteban, cit. (n. 16), III, pp. 59-60.

${ }^{18}$ Cañizares incluye entre las penas infamantes de derecho en el Antiguo Régimen francés los azotes ejecutados públicamente "a los que a veces se añadía una marca". CAÑIZARES NAVARRO, J. B., cit. (n. 12), pp. 113, 123 y 126.

19 Cañizares Navarro, Juan B., cit. (n. 12), p. 108. 
una concepción estricta que mantenemos, consideramos que las penas corporales son aquellas cuyo objetivo principal es causar un daño en el cuerpo del delincuente sin llegar a provocar la muerte ${ }^{20}$. En base a este concepto, a la hora de analizar la evolución histórica de la tipología de estas sanciones, dejábamos a un lado las marcas, por entender que su fin no era la simple represión y el daño físico (pese a que también lo causaba) sino afectar a la estima del reo en la sociedad e identificarlo (excepto las que se aplicaban en una parte del cuerpo oculta ${ }^{21}$. Entendemos que era la integridad física del delincuente la que se veía afectada con la pena corporal y no su libertad, aunque algunos autores han considerado las penas privativas de libertad como corporales ${ }^{22}$ y otros incluyen las corporales y las aflictivas en una misma categoría ${ }^{23}$, siguiendo una concepción amplia que abarca muy diferentes sanciones caracterizadas por infligir un sufrimiento ${ }^{24}$.

Por su parte, las penas infamantes serían aquellas cuya finalidad principal radicaba en ocasionar la infamia del reo, es decir, afectar a su honor ${ }^{25}$ y a su reputación en la sociedad ${ }^{26}$. Hay quien prefiere denominar a estas penas humillantes o

${ }^{20}$ Por el contrario, según Lalinde, la pena de muerte era "la máxima” de las penas corporales. Lalinde Abadía, Jesús, Iniciación histórica al derecho español (Barcelona-Caracas, México, 1a ed., 1970; 2a ed. actualizada, 1978), p. 652, de la 2a ed.

${ }^{21}$ Cfr. Zambrana Moral, Patricia, Rasgos generales de la evolución histórica de la tipología de las penas corporales, en REHJ., 27 (Valparaíso 2005), p. 198.

${ }^{22}$ Sainz Guerra, Juan, cit. (n. 1), p. 288.

23 GutiérreZ, José Marcos, cit. (n. 17), p. 114.

${ }^{24} \mathrm{Al}$ comparar las penas corporales en el derecho hispánico e inglés de la Edad Moderna, Iglesias Rábade incluye en su concepto de pena corporal las marcas ya que se ocupa de las sanciones que implican "en el cuerpo humano una merma de su integridad física o un señalamiento temporal” (vergüenza pública) o perpetuo (impresión de marca a hierro candente)". IGLESIAS RÁBADE, Luis, Estudio comparado de las penas corporales en el derecho hispánico e inglés en la Edad Moderna, en $A H D E$. 86 (2016), p. 299, nota 6.

${ }^{25}$ Aunque no vamos a entrar en el concepto de honor, efectúa una aproximación al mismo y a su protección, Masferrer Domingo, Aniceto, La pena de infamia en el derecho histórico español. Contribución al estudio de la tradición penal española en el marco del ius commune (Madrid, Dykinson, 2001), pp. 27-32. Se trata del estudio más completo sobre la pena de infamia en nuestro Derecho histórico y, pese a que no compartamos algunas de sus conclusiones, es de obligada referencia al hilo de nuestra exposición.

${ }^{26}$ Sobre el origen del nombre "penas infamantes", Cañizares precisa que la doctrina denominó así a las penas cuyo "denominador común era que su imposición y ejecución pretendía lesionar única o fundamentalmente el honor de los condenados", es decir, tenían como "objetivo único o principal” infamarlos. El adjetivo i n $\mathrm{f} \mathrm{a} \mathrm{m}$ a $\mathrm{n} \mathrm{t}$ e procede del término i n $\mathrm{f} \mathrm{a} \mathrm{m}$ i a , siendo esta una "institución jurídica” del derecho romano, "cuyos efectos menoscababan el honor de los condenados", disminuyendo su "buena fama” y su "dignidad civil". La buena fama se definía en el Digesto por Calístrato como "el estado de ilesa dignidad, comprobado por las leyes y las costumbres", haciendo referencia "a la estimación civil, a la consideración y a la dignidad exterior que se tenía por ser un ciudadano romano con el disfrute de todos los privilegios públicos y privados que esta clase llevaba anejos”. CaÑIZAREs Navarro, Juan B., cit. (n. 12), pp. 108 y 133-134. Etimológicamente, el término infamia alude a la pérdida en la comunidad del "honor o dignidad personal", tanto por transgredir las leyes positivas, como las normas morales "pacíficamente aceptadas". CAMACHO DE LOS Ríos, Fermín, La infamia en el derecho romano (Alicante, Generalitat Valenciana, Conselleria de Cultura, Educació i CiènciaInstituto de Cultura "Juan Gil-Albert”, Diputación provincial de Alicante, 1997), p. 43. Ver 
degradantes o infamantes en sentido amplio para diferenciarlas de la pena jurídica de infamia procedente del Derecho romano, en base a sus consecuencias jurídicas ${ }^{27}$, aunque nada impediría considerar esta última un tipo de pena infamante junto a las marcas, entre otras ${ }^{28}$. En consecuencia, históricamente la infamia puede ser tanto una pena en sí misma, como un efecto de otras penas. De hecho, "la huella permanente" que dejaba la marca en el delincuente, a pesar de no tener "otros efectos privativos de derechos, como mínimo hacía perder la buena fama requerida para testimoniar" ${ }^{29}$ con lo que tendría un evidente efecto jurídico infamante, de ahí su relación con la infamia. A nuestro entender, si la marca repercutía en el honor del reo y además lo privaba de derechos, aunque solo fuese del derecho a testificar, sería jurídicamente infamante. No tendría sentido establecer una consecuencia jurídica a una situación que, en principio, solo tendría efectos de cara a la opinión pública.

\section{La marca como pena infamante. Discusión doctrinal}

En base a lo anterior, sostenemos que para concretar la naturaleza jurídica de

Abel Hendy Jones Greenidge, Infamia. Its place in roman public and private law (Oxford, 1874, reimp. Scientia Verlag Aalen, 1977), p. 37.

${ }^{27}$ Confirma la "inexistencia de una noción jurídica clara" de la pena de infamia, aspecto que ya había constatado Fernández de Buján, MASFerrer Domingo, Aniceto, cit. (n. 25), pp. 28, 32-38 y 393. Sigue el criterio de Carrara para quien solo sería i n $\mathrm{f} \mathrm{a} \mathrm{m} \mathrm{a} \mathrm{n}$ t e "aquella pena en la que la infamia es irrogada por medio de una formal declaración de la ley". Por ello, únicamente se ocupa de las penas jurídicamente infamantes, es decir, las establecidas como tal por la ley o por la práctica jurídico-criminal de cada momento histórico (p. 36) y apenas efectúa referencia a la marca. Véase FERNÁNDEZ DE BuJÁN, A., Observaciones acerca de las nociones de ignominia e infamia en derecho romano, en Homenaje a Juan Berchmans Vallet de Goytisolo (Madrid, Junta de Decanos de los Colegios Notariales de España, Consejo General del Notariado, 1988), pp. 313-341.

${ }^{28}$ Para Gutiérrez Fernández, la marca era una de las formas de la pena de infamia de la que se abusaba para "hacer distinciones absurdas". GutiérRez FernÁndez, Benito, cit. (n. 4), p. 98. Sin embargo, Masferrer, al distinguir la pena de infamia de otras "análogas de carácter humillante o ignominioso" o i $\mathrm{n} \mathrm{h} \mathrm{u} \mathrm{m} \mathrm{a} \mathrm{n}$ a $s$, solo parece aceptar la primera como pena infamante, aunque admite que aquellos calificativos podían ser sinónimos de i $\mathrm{n} f \mathrm{f} \mathrm{m}$ a $\mathrm{n} \mathrm{t} \mathrm{e}$, entendido este término en sentido amplio (infamia de hecho) y no técnico-jurídico (infamia de derecho). Masferrer Domingo, Aniceto, cit. (n. 25), pp. 31-36. Por tanto, se basa en que la pena produzca solo efectos en la opinión pública o en que también conlleve consecuencias jurídicas. No compartimos estas sutilezas terminológicas ya que, como hemos indicado, defendemos que, aparte de la pena de infamia stricto sensu, podría haber otras penas infamantes "en sentido técnico-jurídico", aunque se entienda en una acepción amplia, y es aquí donde se ubicaría la marca.

${ }^{29}$ Así lo indica el propio Masferrer entre las escasas referencias que realiza a la marca, aunque afirma que no toda pérdida del derecho a testificar procede de la pena jurídica de infamia. MasFERRER DOMINGo, Aniceto, cit. (n. 25), p. 37. Considera superada la distinción que efectuaba, en otra ocasión, entre penas estrictamente y extensamente infamantes, en la que parecía incluir la marca en la primera categoría por irrogar solo un daño moral al delincuente y no conllevar "otros efectos privativos de derechos". Masferrer Domingo, Aniceto, La pena de infamia en las Costumbres de Horta, en VII Centenari dels Costums d'Orta (1296-1996). Actes de les Jornades d'Estudi (Orta, 25-27 octubre 1996) (Horta de Sant Joan, Ajuntament d'Horta de Sant Joan, 1997), p. 335. Se reproduce el texto de las Costumbres en pp. 353-379. 
la marca habría que tener en cuenta sus efectos y determinar si la finalidad principal de la pena es causar un daño o afectar al honor y a los derechos vinculados al mismo. De hecho, algunas penas infamantes o humillantes, entendiendo el concepto en sentido amplio, también podían tener los efectos jurídicos clásicos de la pena de infamia (pérdida de derechos públicos o privados).

En este sentido, García Goyena y Aguirre situaban la marca en la tipología de penas infamantes, añadiendo a dicha categoría la declaración de infamia y la argolla o exposición a la vergüenza pública ${ }^{30}$. Lalinde también consideraba la marca como pena infamante por su carácter, afirmando la existencia de penas específicamente infamantes, aunque de "menor importancia cuantitativa". Estas se desarrollaron en la Alta Edad Media, y se "incorporan a los ordenamientos nacionales en la Baja Edad Media", afectando algunas al cabello por ser "un signo de dignidad en el ser humano"31. Tanto el que era marcado como el mutilado sufría una evidente h u m ill a c i ó n y una señal perpetua que permitía conocer su reincidencia, con la diferencia de que este último sería, tal vez, el principal objetivo de la marca (el que persigue "con carácter especial"); mientras que la mutilación buscaría, en primer lugar, el castigo físico. Por esta razón, las marcas dejan de tener sentido en la codificación cuando aparecen "los sistemas modernos de identificación" para constatar la reincidencia (registros de penados, dactiloscopia...) ${ }^{32}$. Otros autores calificaban las sanciones cuyo único fin era "la pública ignominia del reo" como "penas de vergüenza pública”, citando ejemplos como correr la villa o la exposición en la picota (se trataría de las "específicamente infamantes", según Lalinde); y las que llevaban "aparejada la nota de infamia” e inhabilitaban al condenado para ejercer derechos como ocupar cargos públicos o testificar en juicio, serían privativas de derechos ${ }^{33}$. De Tapia no aludía a la marca ni entre las penas de infamia, ni entre las corporales ${ }^{34}$.

${ }^{30}$ La marca era la pena infamante con menos ventajas y más inconvenientes, convirtiéndose en "cruel y desmoralizadora, cuando se llevaba en parte ostensible del cuerpo, pues la afrenta perenne que causaba, impedía que entrase en el corazón del criminal sentimientos de agradecimiento”. Tal vez pudo ser útil en alguna ocasión como medio de policía, dejando de tener sentido cuando los gobiernos tuvieron en su mano otros más eficaces. GARCía GOYENA, Florencio y Aguirre, Joaquín, cit. (n. 3), III, pp. 101-102. Sobre las penas infamantes, ver pp. 97-102.

31 LaLinde Abadía, Jesús, Las culturas, cit. (n. 2), II, p. 828.

${ }^{32}$ Lalinde Abadía, Jesús, Iniciación, cit. (n. 20), pp. 656-657, de la 2a ed. Hay testimonios de registros de penas en virtud de una Pragmática de 9 de junio de 1500, aunque estos libros no tenían "el fin de los modernos registros" y no se usaban "con exclusividad", para determinar la reincidencia, "lo que hubiera podido evitar las marcas corporales”. LALINDE ABADíA, Jesús, Las culturas, cit. (n. 2), II, p. 830.

33 Planas Rosselló, Antonio, El derecho penal histórico de Mallorca (siglos XIII-XVIII) (Palma, Universitat de les Illes Balears, 2001), pp. 157-158 y 173. No alude Planas Rosselló a las marcas en su clasificación. Más acertado es el criterio que encuadra la pena de infamia entre las privativas de derechos a partir de "la tipología penológica moderna". MASFERRER DOMINGO, Aniceto, cit. (n. 25), pp. 28 y 175.

${ }^{34}$ Vinculaba los efectos de las penas a la personalidad del reo, de forma que las de infamia podían ser, en ocasiones, "tan terribles y aflictivas como las corporales" si se imponían a "sujetos pundoronosos". De hecho, pensaba que solo se debían aplicar a estos, castigando a los que no tenían pudor con penas corporales y "reservando las infamantes" para los que estimaban 
A la hora de determinar la naturaleza jurídica de la pena de marca no podemos obviar la distinción entre infamia de hecho y de derecho ${ }^{35}$. Tendríamos que plantearnos si la marca producía un efecto infamante de derecho, lo que nos permitiría incluirla en la categoría de penas infamantes. Es obvio que cualquier sanción y sobre todo las corporales (que por ello no se aplicaban a los nobles en Aragón) ocasionaban la mala fama o infamia de hecho del condenado ${ }^{36}$, en el sentido de afectar a su consideración social e implicar una humillación para el mismo, aunque, a veces, también tenían otros efectos jurídicos infamantes relativos a la pérdida de derechos, entre ellos del derecho a testificar, como decíamos anteriormente. Sin embargo, no es fácil distinguir en la historia las conductas que además de causar infamia de hecho (ante la opinión pública), también irrogaban infamia de derecho, despojando a su autor no solo del honor sino también de los derechos

la honra e incluso la preferían a la vida. La infamia sería "una pérdida o menoscabo del honor o de la reputación" del hombre, una "especie de marca impresa" (en clara alusión a la marca histórica que estamos analizando) que lo separaba y distinguía de aquellos que merecían "el aprecio público". De TAPIA, Eugenio, Febrero Novísimo, o librería de jueces, abogados y escribanos, refundida, ordenada bajo nuevo método, y adicionada con un Tratado del juicio criminal, y algunos otros (Valencia, Imprenta de Ildefonso Mompié, 1829), VII, pp. 45-46 y 47. Sobre las circunstancias que debían concurrir para que la pena tuviera los "saludables efectos" que debe proponerse el legislador, véase pp. 46-48. De esta obra hubo tres ediciones entre 1828 y 1845 y fue reeditada en Paris en 1850 y 1861. Gibert y SÁNCheZ de la Vega, Rafael, cit. (n. 3), p. 594). En las diversas versiones que hemos consultado de la Librería de Escribanos o Instrucción jurídica teórico-práctica de principiantes de José Febrero es distinto el tratamiento de las marcas. Cfr. GutiérReZ, José Marcos, Febrero reformado y anotado, o Librería de escribanos que compuso don Joseph Febrero Escribano Real y del Colegio de la corte, y ha reformado en su lenguaje, estilo, método y muchas de sus doctrinas ilustrándola, y enriqueciéndola con varias notas y adiciones para que se han tenido presentes las Reales Órdenes modernas ( $2^{a}$ ed., Madrid, Imprenta de Villalando, 1802), 5 volúmenes.

${ }^{35}$ Masferrer situaba la diferencia entre ambas en que "la deshonra se inflija por juicio de los hombres o por sanción de la Ley" (para Ulpiano la primera sería natural y la segunda civil). Sin embargo, también admite la pena jurídica de infamia de hecho y no solo de derecho con lo que parece incurrir en cierta contradicción, distinguiendo entre penas jurídicamente infamantes de hecho o de derecho y el carácter infamante (en sentido amplio, no técnico) de algunos castigos. Masferrer Domingo, Aniceto, cit. (n. 25), pp. 36-38. Cañizares recoge, siguiendo a Muyart de Vouglans, la distinción entre penas infamantes de derecho y de hecho. La infamia propiamente dicha solo existía en las de derecho, que eran aquellas "cuya consecuencia única o principal era deshonorar a través de la infamia", mientras que los otros castigos provocaban el deshonor, pero no la infamia, aunque "no hay unanimidad en la doctrina sobre las penas a incluir en cada categoría". CAÑIZARES NAVARRO, J. B., cit. (n. 12), pp. 109-111. Respecto a la gravedad de cada tipo, ver pp. 132-135. También distinguía entre infamia de hecho y de derecho, De TAPIA, Eugenio, cit. (n. 34), pp. 45-46.

${ }^{36}$ Según las Partidas, ocasionaban infamia "las sentencias de traición, falsedad, adulterio u otro yerro, y, especialmente las corporales". Es decir, cualquier sentencia por delito implicaba "un efecto infamante, y en este sentido todas las penas son infamantes, pues independientemente del daño corporal o patrimonial infligen un daño moral". A veces, se aumentaba la mala fama con la ejecución pública, sobre todo de los azotes que podían llevar aparejada "la corrida", o con la exposición del cadáver. LaLinde Abadía, Jesús, Iniciación, cit. (n. 20), p. 656, de la 2a ed. y Las culturas, cit. (n. 2), p. 828. Así, las tipologías de las penas servirían de poco porque "hay penas difícilmente encuadrables en un solo grupo". MASFERrer Domingo, Aniceto, cit. (n. 25), p. 175, nota 692 . 
para cuyo ejercicio se requería cierto grado de dignidad ${ }^{37}$. La infamia en sentido jurídico suponía la pérdida de ciertos derechos, afectando al honor del individuo y llevándolo a la marginación social. Así, había penas que llevaban aparejada dicha infamia jurídica, existiendo también la pena de infamia en sentido estricto. Pese a que "la doctrina mayoritaria consideró que la infamia de hecho no producía efectos jurídicos", había quien defendía que podía cerrar el acceso a la judicatura y a otros cargos públicos (échevin, cónsul, administrador de hospitales), llegando incluso a excluir, a veces, de estos oficios ${ }^{38}$. Así, la infamia de hecho "nace de la opinión pública, de la consideración social de mala reputación o deshonor”, sin tener "un referente jurídico ni en el supuesto de hecho que la genera, ni [...] en sus consecuencias jurídicas derivadas", pero esto no implica que "carezca de efectos jurídicamente relevantes, sino que de existir estos, no están predeterminados normativamente" 39 .

Entendemos que la débil línea de separación a la hora de ubicar la marca en la categoría de pena corporal o infamante radicaría, como hemos dicho, en su finalidad ${ }^{40}$. Si se pretendía causar un simple daño físico, en mayor o menor medida, en el cuerpo del delincuente se situaría entre las penas corporales. Si por el contrario, el objetivo principal era reconocer al reo e identificarlo tanto a él como al delito que había cometido y conocer su reincidencia (de ahí los diferentes tipos de marcas: fuego, cortes, tatuajes...), optaríamos por incluirla entre las penas infamantes. A su vez, en esta categoría, la marca podría afectar al honor y reputación, sin ulteriores consecuencias jurídicas, o provocar infamia con efectos jurídicos. En esta línea, Lalinde distinguía tres clases de penas infamantes: aquellas que tenían un fin o "un efecto específicamente infamante", porque el daño físico o patrimonial que ocasionaban era leve; las que causaban un daño relevante y además se acentuaba la infamia "por la forma de ejecución" y las que dejaban una "huella permanente" que permitía identificar al delincuente ${ }^{41}$. Nosotros incluiríamos la marca en la primera y tercera categoría y dudamos del carácter infamante de la segunda.

Concluyendo, podemos afirmar que la marca, en sentido estricto e históricamente considerada, no perseguía como castigo el daño físico (por lo que, en muchas ocasiones, era muy leve) sino la infamia del reo, pero no solo ante la opinión pública (infamia de hecho), sino que también tenía consecuencias jurídicas (infamia de derecho), llevando al delincuente al denominado status jurídico de

37 Así lo afirma Masferrer Domingo, Aniceto, cit. (n. 25), pp. 34-35.

38 Es la opinión de Loiseau que recoge Cañizares Navarro, Juan B., cit. (n. 12), pp. 129-130, nota 125 .

39 Camacho de los Ríos, Fermín, cit. (n. 26), p. 49.

${ }^{40}$ En este sentido se pronunciaba Cañizares al señalar que "la mayoría de penas capitales, corporales y aflictivas llevaban aparejada la infamia"; de modo que el "adjetivo" "infamante" se usó, como vimos, para referir aquellas que tenían "como única o principal finalidad el irrogar infamia a los condenados, mientras que las otras tres categorías de penas producían otros efectos con carácter principal”. CAN̄izares Navarro, Juan B., cit. (n. 12), pp. 110-111 y 127.

${ }^{41}$ Lo deduce Masferrer de lo que expone Lalinde Abadía, Jesús, Iniciación, cit. (n. 20), pp. 656-657, de la 2a ed. Masferrer Domingo, Aniceto, cit. (n. 25), p. 36. Cfr. Lalinde Abadía, Jesús, Las culturas, cit. (n. 2), II, p. 828. 
infame que implicaba que resultase "jurídicamente privado del honor" y de todos los "derechos para cuyo ejercicio se requiere un mínimo de buena fama", disminuyendo su capacidad jurídica ${ }^{42}$. Era la imposición de la marca lo que determinaba la irrogación de la infamia, y esto sería un motivo más para considerarla una pena infamante ${ }^{43}$ o una sanción que afectaba a la dignidad o estimación ${ }^{44}$, siendo esta nuestra postura al respecto.

\section{LA MARCA EN EL DERECHO HISTÓRICO ESPAÑOL}

\section{MEDIEVAL}

Tras analizar una selección de normas de los sistemas jurídicos del derecho histórico español medieval mostramos, a continuación, algunos ejemplos de la presencia de la pena de marca en las mismas, así como su evolución posterior en la Edad Moderna.

\section{Derecho visigodo}

En el derecho visigodo, y, en concreto, en el Liber Iudiciorum ${ }^{45}$ era frecuente la decalvación (decalvatio) considerada por Minguijón como "pena típicamente

${ }^{42}$ Masferrer Domingo, Aniceto, cit. (n. 25), pp. 148, 338 y 396. Analiza con detalle los efectos jurídicos de la infamia en los diferentes derechos históricos que, con algunos matices, vienen a coincidir y que se pueden resumir en la pérdida de la capacidad testifical; incapacidad de acusar en juicio criminal, salvo por injurias dirigidas al reo o a sus allegados; inhabilitación para "ejercer cargo u oficio público que llevara consigo algún honor o dignidad" y pérdida del que tuviese... (pp. 56-58, 73, 81-82, 99-103, 114-120, 148-151, 183-186, 244-258, 300-305, 337-345, 355-363 y 396-397). Los efectos de la infamia iban referidos "a situaciones profesionales o judiciales" cuyo "ejercicio requería unas cualidades morales ejemplares tanto por la importancia de la profesión o función" "como por las consecuencias que la conducta de esas personas podía ocasionar en otros”. Cañizares Navarro, Juan B., cit. (n. 12), p. 130). Sobre la limitación de la capacidad jurídica que ocasionaba la infamia, ver CAMACHO DE LOS RÍOS, Fermín, cit. (n. 26), p. 43.

43 A lo largo de la historia, las causas por las que se sufría la infamia eran de tres tipos: 1) ejercer ciertos oficios o llevar a cabo determinadas actividades; 2) observar conductas contrarias a la moral y a las buenas costumbres, y 3) por haber sufrido la imposición y ejecución de determinadas penas. CaÑIZAREs NaVArro, Juan B., cit. (n. 12), p. 108, nota 13. Ubicaríamos la marca en la tercera causa desencadenante de infamia.

44 De estas hablaba Calístrato, aunque no incluía la marca, pero sí los azotes con varas (fustibus) [D. 50, 13, 5, 3 (Calístrato, I, de cognitionibus)]. Cfr. C. 2, 12, 16 (es infame el azotado por calumnias).

${ }^{45}$ Consultamos varias ediciones del Liber Iudiciorum que citamos cuando hay discrepancia: Los Códigos españoles concordados y anotados (Madrid, Imprenta de la Publicidad a cargo de M. Rivadeneyra, 1847), I; Bellés i Sallent, J., con la colaboración de Alturo, J., Font i Rius, J. M., Mundó, A. M. y Olivar, A., Llibre dels judicis. Traducció catalana moderna del Liber iudiciorum (Generalitat de Catalunya, Departament de Justícia i Interior, Barcelona, 2008) y Alturo, J., Bellès, J., Font i Rius, J. M., García, Y. y Mundó, A. M., (eds.), Liber Iudicum Popularis. Ordenat pel jutge Bonsom de Barcelona (Generalitat de Catalunya, Departament de Justícia i Interior, Barcelona, 2003). La mayor parte de las normas del Liber Iudiciorum examinadas se mantienen en la versión castellana vulgarizada (Fuero Juzgo), por lo que las referimos de forma conjunta, para evitar repeticiones (en este caso, seguimos la edición de Los Códigos españoles concordados y anotados, I). 
infamante" ${ }^{46}$. La misma opinión sostenía Orlandis, siendo esta pena recibida en otros ordenamientos por influjo del derecho visigodo ${ }^{47}$. Puyol Alonso aludía a la posibilidad de que fuese un tipo de marca ${ }^{48}$. La cuestión sería determinar si nos encontramos ante una marca como pena infamante principal que, sin llegar a causar el daño físico de otras penas corporales, tendría idénticos efectos jurídicos infamantes, aunque en estas últimas fuese accesorio (entre ellos la privación de derechos como la pérdida de la capacidad testifical o la imposibilidad de ocupar cargos públicos $)^{49}$. Esta hipótesis se podría mantener si la decalvación consistía en un simple rapado o trasquilado de la cabeza con un fin infamante o si llevaba consigo lesiones menores en su aplicación como desollar la frente. Por el contrario, sería más difícil sostener el carácter de pena infamante si implicaba daños mayores como la extirpación del cuero cabelludo, en cuyo caso, sería considerada una pena corporal. Sin embargo, el problema radica en que no se sabía "a punto fijo cómo se ejecutaba" ${ }^{\prime 0}$.

En cualquier caso, no nos cabe duda de que su finalidad principal sería infamante cuando implicaba lesiones, teniendo en cuenta que el reo quedaba señalado

46 Minguijón, Salvador, Historia del derecho español (Barcelona-Buenos Aires, Labor, 1926), I, p. 64.

47 Orlandis Rovira, José, Las consecuencias del delito en el derecho de la Alta Edad Media, en AHDE., 18 (1947), p. 64. Sobre la pena de infamia en la España visigoda como "instrumento jurídico-público" con una función social y política, véase MASFERrer DOMINGO, Aniceto, cit. (n. 25), pp. 130-155. Cfr. Liber Iudiciorum, 2, 1, 6, ed. de Los Códigos, cit. (n. 45), I, y Liber Iudiciorum, 2, 1, 8, ed. del juez Bonsom, cit. (n. 45) y trad. catalana de Bellés, J., cit. (n. 45). Ver Fuero Juzgo, II, 1, 6.

48 Puyol Alonso, J, Orígenes del Reino de León y de sus instituciones políticas (León, Editorial Nebrija, 1979), pp. 380-381.

49 Orlandis Rovira, José, cit. (n. 47), p. 62.

${ }^{50}$ Esta cuestión fue evidenciada por Minguión, Salvador, cit. (n. 46), I, p. 64. De hecho, en el propio Liber, como veremos, a veces, se hablaba simplemente de decalvatio y otras de decalvationis foeditatelfeditate, perennem infamiam deformiter decalvetur, turpiter decalvatio perhenni infamio, turpiter decalvatione foedati, turpiter decalvatio o decalvati deformiter, intuyéndose mayor gravedad en estas últimas locuciones. En el glosario incluido en una de las ediciones del Liber Iudiciorum que hemos manejado se define decalvare como ad cutem caput radere (afeitado de piel y cabeza); decalvatio como poena ad ignominiam et injuriam per abscissionem capillorum inflicta (lo que parece aludir al carácter ignominioso e infamante de una pena consistente en el corte del cabello) y turpare como mutilare, laedere (mutilar, herir). Los Códigos, cit. (n. 45), I, pp. 90 y 92. De aquí podríamos deducir que cuando se habla solo de decalvatio estaríamos ante una pena infamante, mientras que cuando se acompaña del término turpiter el daño físico sería mayor por lo que podría tener el carácter de pena corporal. En el Fuero Juzgo, aparecen las expresiones sennalar en la fruente, desfollar muy laydamientre toda la fruente [de forma ignominiosa], sennalar laydamientre por desondra desí por todos tiempos, esquilar la cabeza laydamientre, rayar la cabeza o simplemente sennalar. Del mismo modo, en el "glosario de voces antiqüadas y raras" que acompaña al Fuero Juzgo, se define laydamientre como fea o afrentosamente; mientras que sennalado laydamientre se equipara a feamente, herido, trasquilado, o ridículamente afeado. Los Códigos, cit. (n. 45), I, pp. 212 y 216. Otras ediciones aludían a decalvat ignominiosament, rapat ignominiosament, deformement decalvat per a infamia perpètua, vergonya de la decalvació, deshonrosament rapats $i$ restin aixi sotmesos per sempre a la infamia, deturpats ignominiosament amb la decalvació, decalvat de manera infamant estableciendo también cierta diferencia, trad. catalana de BELLÉs, J., cit. (n. 45). 
de forma permanente. En este sentido, Lalinde incluía la decalvación entre las penas infamantes, siendo una forma de irrogar la ignominia por "la importancia que el cabello largo" tenía entre los germanos, a diferencia de los romanos ${ }^{51}$. No obstante, también evidenciaba su carácter corporal por infligirse al condenado, aparte del "corte del cabello", "lesiones en el cuero cabelludo", sobre todo en la frente al ser "decalvado torpemente" (turpiter decalvatus), por ello, como dijimos, además de una pena era una marca por dejar una huella perpetua que facilitaba conocer la reincidencia ${ }^{52}$.

Para otros, la decalvación era una pena corporal que solía acompañar a los azotes, constituyendo "el signo o la marca de la persona infamada, en una sociedad en la que solo quedaba registrado lo que podía percibirse por los sentidos”. Así, los azotes "no se aplicaban de forma exclusiva, sino que llevaban consigo otras medidas penales de carácter humillante", siendo la "condición de infame vitalicia" "perceptible en numerosas ocasiones por la marca corporal" ${ }^{53}$. En estos supuestos, se podría hablar de la concurrencia de dos tipos punitivos, de un lado, los azotes como pena corporal y de otro, la marca en forma de decalvación como pena infamante, siendo obvio que el castigo físico se conseguía con los azotes mientras que la decalvación perseguía como fin principal la infamia.

Entrando ya en casos concretos, la imposición de la decalvación junto a los azotes era muy frecuente en los delitos cometidos por siervos ${ }^{54}$. Así, se castigaba con esta pena (decalvationis foeditate) (además de trescientos azotes) el rapto cometido

51 Lalinde Abadía, Jesús, Las culturas, cit. (n. 2), II, p. 806. Duda si los gothi y los hispani se diferenciaban "por la longitud de sus cabellos" y de ser así, si la decalvación implicaba "una degradación por pasarse del grupo social dominante y exento al grupo dominado y tributario", al margen de que también caracterizaba "la condición religiosa". En la Edad Media, era frecuente "el rapado del delincuente o del loco, que deviene así tonsurado o tonto (tonsus)" (p. 828). Sobre el carácter deshonroso de la decalvación "entre los hombres de raza gótica”, ver OLIVER, Bienvenido, cit. (n. 11), III, p. 391. La tonsura se podía considerar una auténtica pérdida de la virilidad, más que una mutilación, recordando el pasaje bíblico de Sansón. REDONDO, Augustin, cit. (n. 15), pp. 192-193. Cfr. Tilander, Gunnar, O uso de rapar a cabeça aos delinquentes e aos loucos, en Leges Hispanicae Medii Aevi (Stockholm, 1959), VIII, pp. 17-22.

52 LaLinde Abadía, Jesús, Las culturas, cit. (n. 2), II, pp. 806, 825 y 830 e Iniciación, cit. (n. 20) p. 656, de la $2^{\mathrm{a}}$ ed. Intuye influencia goda en una condena en Francia en el siglo XIII que consistía en el "corte del cabello de tal forma que la sangre salga de la cabeza". LALINDE ABADía, Jesús, Las culturas, cit. (n. 2), II, p. 828.

53 Masferrer Domingo, Aniceto, cit. (n. 25), pp. 147 y 269. La infamia visigoda casi siempre se aplicaba de forma accesoria a través de "penas corporales como los azotes, la marca y la decalvación" e implicaba "la infamia jurídica con todas sus penosas consecuencias para la persona del reo" (pp. 269 y 394). La “expresión turpiter decalvatus" aludía al "signo externamente perceptible de la persona que había incurrido en infamia” (pp. 150 y 152). También Iglesias Rábade incluía en la tipología de penas corporales del Fuero Juzgo, junto a las mutilaciones, los azotes y el talión, el marcado infamante, la decalvación y el desollamiento. IGLESIAS-RÁBADE, Luis, Las penas corporales en el derecho hispánico e inglés en la Edad Media. Estudio comparado, en REHJ., 38 (2016), p. 131. Véase SAINZ Guerra, Juan, cit. (n. 1), p. 294.

${ }^{54}$ Indica Sainz Guerra que "marcar a un siervo debía ser una práctica muy habitual contra los recalcitrantes, incluso no mediando sentencia judicial” y por este motivo, una ley de Égica prohibió "a los señores marcarlos sin justa causa (además de otras mutilaciones), imponiéndose una pena de destierro de cinco años si se incurría en dicha infracción”. SAINZ GUERRA, Juan, 
por un siervo sobre mujer libre ${ }^{55}$, siendo desollada su frente (turpiter decalvatus) junto a cien azotes si dicha mujer antes fue sierva y tenía hijos con ella ${ }^{56}$. El rapto entre siervos se sancionaba con doscientos azotes y la decalvación (decalvatus) ${ }^{57}$. El esclavo que vendía a un hombre o a una mujer libre era castigado con los mismos azotes y la decalvación (decalvatus turpiter), además de entrar al servicio perpetuo de aquel a quien había vendido ${ }^{58}$. El siervo que, bajo tormento, confesaba haber matado a otro hombre libre o siervo por mandato de su señor recibía cien azotes y era decalvado (turpiter decalvandi), aunque no pagase por el homicidio; y el hombre libre que conspiraba con otro para cometer un homicidio se penalizaba con doscientos azotes, la decalvación (decalvationis foeditatem) y cincuenta sueldos destinados a los parientes del muerto, pasando, en caso de insolvencia, a ser esclavo de estos ${ }^{59}$. El siervo nacido de la unión de un cristiano y un judío debía abrazar el cristianismo y, de lo contrario, era azotado públicamente, decalvado (turpiter decalvati) y entregado como esclavo a un cristiano ${ }^{60}$.

El que ocasionaba un daño a otro alegando ignorancia de las leyes se sancionaba con el talión, cien azotes y perennem infamiam deformiter decalvetur, vinculándose aquí de forma clara la decalvación con una marca deformante que ocasionaba infamia perpetua ${ }^{61}$. Si se probaba que una persona inducía a otra a cometer falso testimonio, mediando o no engaño, ambos eran condenados como falsarios y recibían, con carácter ejemplarizante, doscientos azotes ejecutados públicamente, siendo decalvados (tupiterque decalvati perhenni infamio subiacebunt) y sometidos a infamia para siempre ${ }^{62}$. Los que dirigían y reclutaban la hueste si desertaban, huían, no se presentaban en el día y lugar establecido, se mostraban negligentes a la hora de ponerse en marcha o se ausentaban de la expedición con una justificación fraudulenta, eran azotados (doscientos azotes), decalvados (turpiter decalvatione

cit. (n. 1), p. 295. No obstante, en dicha norma no se hacía referencia alguna a la marca, sino a diferentes tipos de mutilaciones (Liber Iudiciorum, 6, 5, 13 y Fuero Juzgo, 6, 5, 13).

${ }_{55}$ Liber Iudiciorum, 3, 3, 8, ser castigado a la vergonya d'ésser rapats, en la trad. catalana de BeLlés, J., cit. (n. 45), y Fuero Juzgo, 3, 3, 8, sennalar en la fruente.

${ }^{56}$ Liber Iudiciorum, 3, 3, 9, ser rapat vergonyosament, en la trad. catalana de BELLÉs, J., cit. (n. 45), y Fuero Juzgo, 3, 3, 9, desfollarle muy laydamientre.

${ }^{57}$ Liber Iudiciorum, 3, 3, 10, ser rapat, en la trad. catalana de BELLÉs, J., cit. (n. 45), y Fuero Juzgo, 3, 3, 10, desfollale la fruente muy laydamientre.

${ }_{58}$ Liber Iudiciorum, 5, 4, 11, decalvat ignominiosament, en la trad. catalana de BELLÉs, J., cit. (n. 45), y Fuero Juzgo, 5, 4, 12, sennalado en la fruente.

59 Liber Iudiciorum, 6, 5, 12, decalvat ignominiosament/vergonya de la decalvació, en la trad. catalana de Bellés, J., cit. (n. 45), y Fuero Juzgo, 6, 5, 12, sennalado/señalado laydamientre.

${ }^{60}$ Liber Iudiciorum, 12, 2, 14, ignominiosament decalvats, en la trad. catalana de BELLÉs, J., cit. (n. 45), y Fuero Juzgo, 12, 2, 14, sennalados laydamientre.

${ }^{61}$ Liber Iudiciorum, 6, 4, 5, deformement decalvat per a infamia perpètua, en la trad. catalana de Bellés, J., cit. (n. 45), y Fuero Juzgo, 6, 4, 5, sennalado laydamientre por desondra desí por todos tiempos.

${ }^{62}$ Liber Iudiciorum, 2, 4, 6, en la ed. del juez BonsOM, cit. (n. 45); deshonrosament rapats $i$ restin així sotmesos per sempre a la infamia, en la trad. catalana de BELLÉs, J., cit. (n. 45). Sobre la interpolación de este texto para agravar la pena, ver AlEjANDRE GARCía, J. A., El delito de falsedad testimonial en el derecho histórico español, en HID., 3 (1976), pp. 36-37. 
foedati) y multados con el pago de una libra de oro que el rey podía adjudicar a quien quisiera ${ }^{63}$.

También era habitual imponer esta pena a los judíos. El que celebraba la Pascua según su costumbre, incumpliendo las leyes, se sancionaba con cien azotes, la decalvación (turpiter decalvatus), el destierro y la confiscación de bienes ${ }^{64}$. El judío que comía carne o no discriminaba los alimentos en contra de la ley cristiana se castigaba con cien azotes y la decalvación (turpiter decalvetur) ${ }^{65}$. Idéntica sanción (decalvetur) ejecutada públicamente, aparte de la corporal, recibía el judío que leía o poseía libros prohibidos contra la fe de Cristo, el maestro que impartía docencia con los mismos ${ }^{66}$, el insolvente que tenía siervos cristianos ${ }^{67}$, el que en idéntica situación económica cometía un delito contra un cristiano ${ }^{68}$, el que no visitaba al Obispo o sacerdotes los días establecidos ${ }^{69}$ o el que se casaba con un pariente ${ }^{70}$. Entre las leyes nuevas contra los judíos se encontraba la que sancionaba al blasfemo contra la Santísima Trinidad con cien azotes, la decalvación (decalvatus) y el destierro ${ }^{71}$.

Los brujos, hechiceros, adivinos y los que hacían sacrificios a los demonios eran flagelados (doscientos azotes) y decalvados (decalvati deformiter) además de recorrer diez villas vecinas como ejemplo ${ }^{72}$. El que abandonaba a su esposa y se casaba con otra era condenado a doscientos azotes, a la decalvación (turpiter decalvatione foedatus) y al destierro, pudiendo el príncipe entregarlo como siervo a quien quisiese ${ }^{73}$. También se imponía la decalvación (turpiter decalvatus) y

${ }^{63}$ Liber Iudiciorum, 9, 2, 9, deturpats ignominiosament amb la decalvació, en la trad. catalana de BELLÉs, J., cit. (n. 45), y Fuero Juzgo, 9, 2, 8, sennalado laydamientre.

${ }^{64}$ Liber Iudiciorum, 12, 3, 4, decalvat ignominiosament, en la trad. catalana de BELLÉs, J., cit. (n. 45), y Fuero Juzgo, 12, 3, 4, ráyanle la cabeza.

65 Liber Iudiciorum, 12, 3, 7, ignominiosament decalvat, en la trad. catalana de BELLÉs, J., cit. (n. 45), y Fuero Juzgo, 12, 3, 7, ráyanle la cabeza laydamientre.

${ }^{66}$ Liber Iudiciorum, 12, 3, 11, decalvat públicament, en la trad. catalana de BELLÉs, J., cit. (n. 45), y Fuero Juzgo, 12, 3, 11, ráyanle la cabeza.

${ }^{67}$ Liber Iudiciorum, XII, 3, 12, decalvats, en la trad. catalana de BeLlÉs, J., cit. (n. 45). En el Fuero Juzgo, 12, 3, 12 se elimina la decalvación y se mantiene como pena los cien azotes y la confiscación. Cfr. Liber Iudiciorum, 12, 3, 13, decalvat, en la trad. catalana de BeLlés, J., cit. (n. 45), y Fuero Juzgo, 12, 3, 13, ráyanle la cabeza.

${ }^{68}$ Liber Iudiciorum, 12, 3, 17, decalvació, en la trad. catalana de BELLÉs, J., cit. (n. 45), y Fuero Juzgo, 12, 3, 17, ráyanle la cabeza.

${ }^{69}$ Liber Iudiciorum, 12, 3, 21, decalvatione fedatus, en la ed. del juez Bonsom, cit. (n. 45) y decalvació pública, en la trad. catalana de Bellés, J., cit. (n. 45), y Fuero Juzgo, 12, 3, 21, ráyanle la cabeza.

${ }^{70}$ Aquí se imponía la decalvación (decalvati), cien azotes, destierro y confiscación de bienes en favor de los hijos que no fuesen fruto de un matrimonio prohibido. Liber Iudiciorum, 12, 3, 8, decalvats, en la trad. catalana de BeLLÉs, J., cit. (n. 45) y Fuero Juzgo, 12, 3, 8, ráyanles las cabezas.

${ }^{71}$ Liber Iudiciorum, 12, 3, 2, decalvatus turpiter, en la ed. del juez Bonsom, cit. (n. 45) y decalvat (de manera infamant), en la trad. catalana de Bellés, J., cit. (n. 45), y Fuero Juzgo, 12, 3, 2, esquilar la cabeza laydamientre.

72 Liber Iudiciorum, 6, 2, 3, [ed. de Los Códigos, cit. (n. 45), I; Liber Iudiciorum, 6, 2, 4, en la ed. del juez Bonsom, cit. (n. 45) y en la trad. catalana de Bellés, J., cit. (n. 45), decalvats deformement, y Fuero Juzgo 6, 2, 4, sennalelos na fronte laydamientre.

73 Liber Iudiciorum, 3, 6, 2, rapat ignominiosament, en la trad. catalana de BELLÉs, J., cit. 
doscientos azotes, junto con la amputación del pulgar de la mano diestra, con independencia de su posición social, a los escribanos que falsificaban documentos reales o a los que alegaban leyes falsas ${ }^{74}$.

Sin mayores especificaciones, en el Fuero Juzgo se establecía que quien reunía a una multitud o encargaba u ordenaba a otro que la reuniese para cometer un delito de homicidio o lesiones debía ser señalado, además de recibir sesenta azotes $^{75}$. Sin embargo, en el Liber Iudiciorum, se indicaba, con carácter general, que sufriese la infamia (infamia notatus) y cincuenta azotes ${ }^{76}$.

\section{Derecho local catalán}

En el derecho local catalán encontramos escasas referencias a la marca ${ }^{77}$. A la hora de analizar las penas en las Costums de Tortosa, Oliver seguía la clasificación establecida por el derecho romano, entre capitales ("que llevaban consigo la pérdida de la vida, de la libertad o del estado civil") y no capitales ("que afectaban al cuerpo, a la libertad o al honor del ciudadano"), por ser "la más adecuada al sentido jurídico del Código", a pesar de dudar de su "rigor científico"78. En el segundo grupo se incluía la marca, a la que otorgaba un tratamiento indepen-

(n. 45), y Fuero Juzgo, 3, 6, 2, sennalado laydamientre.

${ }^{74}$ Liber Iudiciorum, 7, 5, 9, decalvat ignominiosament, en la trad. catalana de BELLÉs, J., cit. (n. 45), y Fuero Juzgo 7, 5, 9, sennalado laydamientre. No se recoge en la ed. del juez Bonsom, cit. (n. 45).

75 Fuero Juzgo, 8, 1, 3, ed. de Los Códigos, cit. (n. 45), I.

${ }^{76}$ Liber Iudiciorum, 8, 1, 3, marcat d'infamia, en la trad. catalana de BELLÉs, J., cit. (n. 45).

77 Respecto a la pena de infamia, Masferrer sostiene que el único texto del derecho municipal catalán que la recogió en sentido jurídico fue las Costums de Tortosa por el influjo romano-justinianeo. Así, en otras costumbres, las sanciones corporales, aunque producían "una humillación" y, a veces, "incluso una marca incruenta en el reo", no eran "jurídicamente infamantes". Masferrer Domingo, Aniceto, La dimensión ejemplarizante del derecho penal municipal catalán en el marco de la tradición jurídica europea. Algunas reflexiones iushistóricopenales de carácter metodológico, en AHDE., 71 (2001), pp. 465 y 467-468; La pena de infamia en las Costumbres, cit. (n. 29), p. 342 y en cit. (n. 25), pp. 155-264 y 393. Atribuye la pérdida de capacidad testifical de los que sufrían penas humillantes "a la mala fama que provenía de su indecorosa conducta” (infamia de hecho ante la opinión pública derivada del delito) y no al "status jurídico de infame irrogado por la pena", exigiendo la mayoría de los textos medievales "la buena fama a los que prestaban testimonio", cit. (n. 25), pp. 156-160. Cfr. Costums d'Orta, 62, cit. (n. 29); Consuetudines Ilerdenses, 133, ed. de Loscertales de Valdeavellano, Pilar, Costumbres de Lérida (Barcelona, Universidad de Barcelona, 1946); Costums de la batllia de Miravet, 105 y 106, ed. de Serrano i Daura, Josep, Els Costums de la batllia de Miravet (Tarragona, Consell Comarcal de la Terra Alta, 1999). Pensamos que esta incapacidad testifical sería, en sí misma, una consecuencia jurídica. De este modo, si solo los que tenían buena fama podían testificar, cualquier pena que hiciera incurrir en infamia produciría el efecto jurídico de privar de la capacidad para actuar como testigo que, por otra parte, era uno de los principales de la infamia y, por tanto, provocaba la privación de un derecho, al margen de la mala fama ante la opinión pública. Por su parte, Estrada habla de penas infamantes (o que llevaban un p 1 u s de infamia) en las Costums d'Orta, acompañando la infamia a todas las sanciones ejecutadas públicamente. Estrada Rius, Albert, L'ordenament jurídico-criminal en els Costums d'Orta", en VII Centenari dels Costums d'Orta (1296-1996). Actes de les Jornades d'Estudi (Orta, 25-27 octubre 1996) (Horta de Sant Joan, Ajuntament d'Horta de Sant Joan, 1997), p. 292.

${ }^{78}$ Oliver, Bienvenido, cit. (n. 11), III, p. 345. 
diente de las penas corporales (mutilación y azotes) y de la pena de infamia y de vergüenza pública. No obstante, afirmaba que "la pena de marca llevaba consigo, como accesoria, la de infamia" 79 . Pensamos que en realidad lo que se reconoce es el efecto infamante de la marca. De hecho, en las Costums hay un título dedicado a la infamia, donde se incluyen entre los infames a los marcados llamados croat ${ }^{80}$. Esta denominación se derivaba de la "señal de la cruz que se imprimía en la cara del reo con el hierro caliente" 81 .

Para Oliver, la infamia en sí misma era una sanción que consistía "en la pérdida del honor y de la reputación”, una "excomunión civil” y "una señal de desaprobación pública" que hacía "perder a una persona la confianza de la patria y de sus conciudadanos", evitando a "estos últimos el trato o amistad con el infamado". Siguiendo la tradición romana, las Costums la imponían como pena principal en determinados casos - "funcionarios públicos destituidos de su cargo por sentencia judicial" 82 , usureros públicos ${ }^{83}$, condenados por hurto, latrocinio, robo, lesiones, homicidio y otros delitos similares (en altre crim semblants a aquests), aunque se les perdonese la sanción impuesta (lo que manifiesta su carácter perpetuo) ${ }^{84}$ y los que cometían falso testimonio que además quedaban para siempre incapacitados para testificar, debiendo indemnizar a la víctima los perjuicios causados ${ }^{85}-\mathrm{y}$ como accesoria de otras penas impuestas por sentencia (azotes, ser corrido por la ciudad, mutilación y marca ${ }^{86}$. Sin embargo, como ya hemos dicho, la marca

79 Ibíd., III, p. 352.

${ }^{80}$ Costums de Tortosa, II, 8, 7. Consultamos la edición de Oliver, Bienvenido, Historia del derecho en Cataluña, Mallorca y Valencia. Código de las Costumbres de Tortosa (Madrid, Imprenta de Miguel Ginesta, 1881), IV y la edición crítica de Massip i FonollosA, J., Costums de Tortosa (col-laboració de Duarte, C. y Massip, À. y “pròleg” de Font i Rius, J. M., Barcelona, Fundació Noguera, 1996). Los infames pertenecían a "la clase de hombres libres cristianos” y eran más humildes que la plebe integrada por colonos y libertos. Los infames y los que tenían "oficios viles o deshonrosos" no podían "ejercer los cargos de juez o de tutor" ni testificar en juicio, pudiendo ser sometidos a la prueba del tormento. Oliver, B., Historia del derecho en Cataluña, Mallorca y Valencia. Código de las Costumbres de Tortosa (Madrid, Imprenta de Miguel Ginesta, 1876), I, p. 44. Por tanto, cualquier pena que irrogase infamia provocaba estos efectos.

${ }^{81}$ Relaciona esta denominación con el hecho de que algunas monedas acuñadas en Barcelona en el siglo XV también recibían este nombre como traducción del término francés crozats con el que se designaban en Francia "otras monedas de plata por llevar grabadas en ellas la señal de la cruz”. Oliver, Bienvenido, cit. (n. 11), III, p. 352. Según Gutiérrez, en Roma la marca tenía la forma de "dos llaves en forma de cruz de San Andrés, que son las armas de su Santidad". GutiérReZ, José Marcos, cit. (n. 17), p. 118.

82 Costums de Tortosa, II, 8, 2.

${ }^{83}$ Costums de Tortosa, II, 8, 5.

${ }^{84}$ Costums de Tortosa, II, 8, 7. Serrano relaciona esta norma con Costums de la batllia de Miravet, 116, donde se establecía la pena para el ladrón (podía oscilar entre correr la villa, una mutilación, una pena pecuniaria o incluso la muerte si era reincidente), afirmando que implicaba infamia para el reo. Serrano i Daura, Josep, cit. (n. 77), p. 72, nota 160 y p. 168. Cfr. LaLinde ABADía, Jesús, Las culturas, cit. (n. 2), II, p. 828.

${ }^{85}$ Costums de Tortosa, IV, 11, 24. Véase Oliver, Bienvenido, cit. (n. 11), III, p. 379.

86 Oliver, Bienvenido, cit. (n. 11), III, pp. 357-358. Oliver identifica vergüenza pública con el término "corregut", planteando dudas al respecto, Masferrer Domingo, Aniceto, cit. (n. 25), pp. 181-182. 
podría situarse como pena infamante principal si su único objetivo era ocasionar infamia y no causaba un excesivo daño corporal.

A pesar de que ya Constantino trató de evitar la aplicación de marcas en la frente por ser la cara del hombre imagen de Dios, las Costums la seguían aplicando ${ }^{87}$. Era la sanción que se establecía de forma subsidiaria, en caso de insolvencia, cuando la pena pecuniaria principal superaba los quince sueldos y no pasaba los treinta, junto con los azotes (uno por cada sueldo) y la vergüenza pública. En estos supuestos, "el delincuente era paseado" casi desnudo (en bragues) por la ciudad y el sayón que lo acompañaba lo azotaba pregonando a gritos el hecho delictivo por el que había sido condenado (qui aytal fara, aytal pendra/quien estos hechos ejecutará, este castigo recibirá” ${ }^{88}$. Aquí el fin de la marca era perpetuar la infamia, ya que el castigo corporal se conseguía con los azotes y la mala fama inicial con la c o r rid a por la ciudad.

La vergüenza pública perseguía la e j e m p l a r i d a d, tenía un gran e f e c t o m o r a l y solía imponerse como accesoria de los azotes ${ }^{89}$. Los que cometían un delito de alcahuetería eran castigados a ser paseados totalmente desnudos sobre un asno por la localidad llevando atravesada la lengua de lado a lado con un hierro, mientras el sayón los azotaba con el referido grito (qui aytal fara, aytal pendra $)^{90}$. Se trataba de una ejecución claramente infamante, y el hecho de atravesar la lengua ocasionaba un daño de tal entidad que lo alejaría de la categoría de la simple marca ${ }^{91}$.

La "corrida" o "azotamiento a través de la villa" era frecuente en las fuentes medievales para sancionar el delito de adulterio ${ }^{92}$. En Valencia, la bigamia se

${ }^{87}$ Oliver, Bienvenido, cit. (n. 11), III, pp. 351-352.

${ }^{88}$ Costums de Tortosa, IX, 25, 22. En palabras de Bienvenido Oliver, existía un "aumento proporcional entre la pena personal y la pecuniaria que dejaba de pagarse" que tenía su origen en la legislación visigoda, atendiéndose para concretar la pena subsidiaria "no al importe de la condena sino a la cantidad que había dejado de satisfacer el reo". Oliver, Bienvenido, cit. (n. 11), III, pp. 363-365.

${ }^{89}$ Oliver, Bienvenido, cit. (n. 11), III, p. 353.

${ }^{90}$ Costums de Tortosa, IX, 2, 8. Ver Oliver, Bienvenido, cit. (n. 11), III, p. 384.

${ }^{91}$ En el derecho valenciano, existía una sanción similar para el falso testigo insolvente que era castigado, de forma subsidiaria, con la perforación de la lengua con un hierro caliente, además de ser azotado recorriendo la ciudad. Fori Antiqui Valentiae, LXII, 19, ed. crítica de Dualde Serrano, Manuel, Fori Antiqui Valentiae (Madrid-Valencia, CSIC, 1950-1967). Sería una pena corporal e infamante. AlEjANDRE GarCía, Juan Antonio, cit. (n. 62), p. 124. En 1301, Jaime II modificó los fueros agravando las penas. Así, cuando el delito se cometía en causa civil, el castigo de ser azotado por la ciudad "portando en la lengua un hierro caliente" dejó de ser subsidiario. Aunque ya no se hablaba de perforación, Alejandre entiende que esta era la forma de ejecución e implicaba una incapacidad física para testificar (pp. 126-127). Consultar AlejandRE GARCÍA, J. A., Falsedad documental y falsedad testimonial. Estudio histórico-juridico de dos tipos delictivos (Madrid, Dykinson, 2012) y Fernandez Espinar, R., El falso testimonio judicial en el derecho español (Granada, Majfer, 2015).

${ }_{92}$ Cfr. Costums de Tortosa, IX, 2, 5; For de Morlaàs, 22 y For d'Oloron, 19. Ourliac, Paul y Pilles, Monique, Les Fors Anciens de Béarn (Paris, CRNS éditions, 1990), pp. 322, 325, 508 y 509; Carta de población de Agramunt. Muñoz y Romero, Tomás, Colección de Fueros Municipales y Cartas Pueblas de los reinos de Castilla, León, Corona de Aragón y Navarra (Madrid, Imprenta de Don José María Alonso, 1847; reed. anastática, Madrid, Lope de Vega, 1972), 
castigaba con pena pecuniaria y, en caso de insolvencia, los bígamos eran corridos por la ciudad y azotados mientras se pregonaba su delito, trasquilados en cruz (tonsoretur) y desterrados de la ciudad y del reino ${ }^{93}$.

\section{Derecho castellano y aragonés}

Por lo que respecta al derecho castellano ${ }^{94}$, descubrimos el recurso a la marca en la forma de rasurado del cabello. En el Fuero de Béjar, una de las penas previstas para los ladrones era la amputación de orejas y el rapado en cruz ${ }^{95}$. El hombre hechicero se trasquilaba, azotaba y desterraba de la localidad ${ }^{96}$ y el que algún enganno fizo en algunas cosas era esquilado y azotado por las calles junto a la mutilación de las orejas ${ }^{97}$. El falso juramento se sancionaba en los Fueros de Cáceres y Usagre trasquilando la mitad de la cabeza ${ }^{98}$.

Una evidente señal perpetua dejaba el castigo previsto para el falso testimonio en el Libro de los Fueros de Castilla y en el Fuero Real consistente en la pérdida de los dientes, además de la incapacidad testifical para siempre ${ }^{99}$. Una disposición

p. 402; Consuetudines Ilerdenses, 15; Costums d'Orta, 9; Costums de la batllia de Miravet, 22; Fuero de Miranda de Ebro, 21, ed. crítica, versión y estudio de CanTERA Burgos, Francisco (Madrid, CSIC, Instituto Francisco de Vitoria, 1945); Fori Antiqui Valentiae, CXIV, 6. Véase Oliver, Bienvenido, cit. (n. 11), III, pp. 365 y 383-384; Serrano i DaUra, Josep, cit. (n. 77) p. 71, nota 156; Planas Rosselló, Antonio, Los delitos contra el matrimonio y la moral sexual en el derecho histórico de Mallorca, en Bolletí de la Societat Arqueològica Lul.liana, 56 (2000), pp. 46-47 y 60 y El derecho penal, cit. (n. 33), pp. 74-75, 80 y 163 y LALINDE ABAdía, Jesús, Las culturas, cit. (n. 2), II, p. 829.

${ }_{93}$ Fori Antiqui Valentiae, CXIX, 44. Se dedica una rúbrica a la infamia (Fori Antiqui Valentiae, XXII) y se declaran infames los condenados por hurto, rapiña, homicidio, adulterio et alio crimine consimili (Fori Antiqui Valentiae, XXII, 6).

${ }_{94}$ Niega la presencia de la pena de infamia stricto sensu en los fueros locales, aunque recogían sanciones humillantes, Masferrer Domingo, Aniceto, cit. (n. 25), p. 267. Ninguna alusión a la marca hacía Orlandis al analizar las penas en la Alta Edad Media, hablando, en general, de "varias especies de penas infamantes" como la flagelación pública del reo o su conducción en forma humillante por las calles de la villa. Orlandis Rovira, J., cit. (n. 47) p. 165.

${ }^{5}$ Fuero de Béjar, 931, ed. de Gutiérrez Cuadrado, Juan, Fuero de Béjar (Salamanca, Secretariado de Publicaciones e Intercambio Científico, Universidad de Salamanca, 1974). También se imponía el trasquilado, sin indicar forma, para el que se hiciera escribir dos veces, en Fuero de Béjar, 932.

${ }^{9}$ Fuero de Béjar, 340.

${ }^{97}$ Fuero de Béjar, 546.

98 Fuero de Cáceres, 294 y Fuero de Usagre, 313. De Ureña y Smenjaud, Rafael y Bonilla y SAn Martín, Adolfo, Fuero de Usagre (siglo XIII). Anotado con las variantes del de Cáceres, (Madrid, Hijo de Reus Editores, 1907), p. 114.

99 Libro de los Fueros de Castilla, 167, ed. de Alvarado Planas, Javier y Oliva Manso, Gonzalo, Los Fueros de Castilla. Estudios y edición crítica del Libro de los Fueros de Castilla, Fuero de los fijosdalgo y las Fazañas del Fuero de Castilla, Fuero Viejo de Castilla y demás colecciones de fueros y fazañas castellanas (Madrid, Centro de Estudios Políticos y Constitucionales, 2004), p. 311, y Fuero Real, IV, 12, 3, ed. de Los Códigos, cit. (n. 45), I. Para "lograr una mayor cohesión en la aplicación de un derecho penal 'general' o territorial, Fernando III ordenó a algunos concejos de la Corona de Castilla" que impusieran "la pena corporal de extracción de dientes a los que juraren y atestiguaren en falso", abandonando "su régimen sancionador local”. IGLESIAS RÁBADE, Luis, El falso testimonio judicial en el derecho hispánico y anglo-sajón en el Medievo. Estudio compa- 
similar encontramos en el Fuero de Ayala al prescribir que al testigo falso sobre juramento, le sean sacados de cinco dientes uno, siempre que se probase ${ }^{100}$. En estos casos, el daño ocasionado con esta sanción nos llevaría a situarla entre las corporales. En el Espéculo se imponía para castigar el delito de perjurio, además de la misma pena sufrida por el perjudicado por el falso testimonio (en base a un criterio talional) y la incapacidad para testificar, la marca en la cara con un hierro candente ${ }^{101}$, aunque, como veremos, sería prohibida por las Partidas ${ }^{102}$.

En el Fuero Real, el clérigo que falsificaba el sello real era desterrado, desordenado y señalado en la frente y sus bienes confiscados en favor del rey. Aquí nos encontramos con la marca como pena infamante con el fin de que todos conozcan el delito para siempre (sea conoscido por falso por jamas) ${ }^{103}$.

No hay referencia expresa a la marca en la tipología punitiva de las Siete Partidas, aunque sí se recogía la infamia como el sexto tipo de pena (dañar la fama de algún judgandolo por enfamado) y las penas corporales como el séptimo (azotes o heridas) ${ }^{104}$. Como hemos dicho, se prohibía, con carácter general, señalar a alguno en la cara quemándole con fuego caliente, cortándole la nariz o sacándole los ojos o de cualquier otro modo que implique una señal en el rostro, porque la cara del hombre la fizo Dios a su semejanza; sin embargo, se permitían estas señales en otras partes del cuerpo, para servir de escarmiento y ejemplo a la sociedad ${ }^{105}$. Ya advertía

rado, en En la España medieval, 40 (2017), p. 88. El Ordenamiento del Rey D. Enrique III, Ley 11 impuso esta pena junto a una multa al que jurase en falso (p. 98, nota 206). En una fazaña del siglo XIII se relataba cómo iba por la villa con los dientes en la mano, incrementando así el efecto infamante y ejemplarizante. LALINDE ABADÍA, Jesús, Las culturas, cit. (n. 2), II, p. 830.

100 Fuero de Ayala, III (aumentado por el mariscal D. García López de Ayala en 1469), ed. de De Uriarte Lebario, L. M. (Madrid, Hijos de M. G. Hernández, 1912; 2a ed. Álava, Diputación Foral de Álava, 1974)]. La misma pena se imponía al que presentaba un testigo falso actuando como inductor y no podía ser conmutada ni sustituida por otra. Era necesario previo juramento para apreciar el delito, de forma que esta sanción solo se aplicaba al falsario perjuro, castigándose la falsedad no jurada "con pena talional compensatoria". IGLESIAS RÁBADE, Luis, El falso testimonio, cit. (n. 99), pp. 89-90 y 97 y Alejandre García, J. A., cit. (n. 62), pp. 23-25, 34, 44-49 y 98-100. Alejandre atribuye el origen de la pena "a un derecho tradicional popular", siendo "una medida punitiva de indudables reminiscencias primitivas y difusa en el pueblo, de donde la recogieron una y otras fuentes", apareciendo en fueros portugueses y en el derecho vasco por influencia castellana (pp. 73 y 108-109). La ejecución era pública buscando "un efecto intimidativo" (p. 110).

101 Espéculo, 5, 12, 30. Esta sanción no se recoge en las Partidas, III, 11, 26 (seguimos la ed. de las Partidas glosada por López, Gregorio (Salamanca, 1555). Cfr. Alejandre García, Juan Antonio, cit. (n. 62), pp. 110-111.

102 Partidas, 7, 31, 6.

103 Fuero Real, IV, 12, 2. Véase Gutiérrez Fernández, Benito, cit. (n. 4), p. 155.

104 Partidas, 7, 31, 4. La infamia se regulaba en Partidas, 7, 6, concretándose el concepto de fama y de infamia en Partidas, 7, 6, 1. Sobre la pena de infamia en el texto alfonsino, véase Masferrer Domingo, Aniceto, cit. (n. 25), pp. 271-313. Afirma que se recoge "de manera extensa" y ordenada, siendo el texto normativo básico para la introducción de esta pena en el ordenamiento castellano, sirviendo de inspiración al derecho real posterior.

105 Partidas, 7, 31, 6. No compartía Lardizábal este argumento porque "la semejanza del hombre con Dios está en el ánimo, y no en la cara, ni en otra parte del cuerpo”. DE LARDIZÁBAL y URIBE, Manuel, cit. (n. 17), p. 92, nota 123. A pesar de la prohibición, a partir de las Cortes de Briviesca de 1387, los bígamos eran castigados con una Q grabada con hierro candente en 
Minguijón la incongruencia de esta norma con la imposición de la letra B en los labios con hierro candente para castigar la reincidencia de los insolventes en la blasfemia ${ }^{106}$. Las Partidas distinguían entre infamia de hecho y de derecho ${ }^{107}$. De todos los supuestos que irrogaban infamia nos interesa la infamia (de derecho) procedente de la ejecución de pena. Así, se menciona al que, por haber sido hallado cometiendo un hurto o alguno de los otros yerros, se le imponía la sanción de heridas u otra pena pública ${ }^{108}$. Aquí se situaría la marca, aunque no haya referencia expresa (pese a que se establecía en algunos casos), por lo que parece que el sentir del texto alfonsino es reconducirla a la categoría de penas corporales.

Entre los delitos castigados con la infamia en general en el derecho aragonés se encontraba la usura ${ }^{109}$. Con el fin de señalar al reo con carácter permanente, en los Fueros de Borja y Zaragoza el testigo falso, siempre que se probase, era trasquilado en cruz y quemado en la frente con el badajo de una campana caliente, también en cruz, como nota de infamia para dar a conocer su delito, además de ser deste-

la frente. Ver Nueva Recopilación, 5, 1, 5 y Novísima Recopilación, 12, 28, 6. También existía la prohibición en Portugal "desde 1524, con Juan III, pero las marcas faciales se recogían en las "Ordenanzas Manuelinas". Lalinde Abadía, Jesús, Las culturas, cit. (n. 2), II, p. 830.

${ }^{106}$ Se trata de lo establecido en Partidas, 7, 28, 4, aunque Minguijón, de forma errónea, habla de Partidas, 7, 18, 4. Minguijón, Salvador, cit. (n. 46), I, p. 191.

107 Partidas, 7, 6, 1, in fine. Los supuestos de infamia de hecho se regulan en Partidas, 7, 6, 2. Según Masferrer, aunque la infamia de hecho depende de "la opinión o sentir de los hombres", al "establecerse expresa y legalmente", algunos casos parecen convertirse en infamia iuris, quedando "la categoría de infamia facti" "juridificada" y perdiendo "hasta cierto punto tal naturaleza de infamia de hecho", pero no en cuanto a los efectos jurídicos. La infamia de derecho se irrogaba por delito, por sentencia y por pena, aunque esta distinción no está clara en Partidas pero sí para Gregorio López. En la versión castellana del siglo XIX de la glosa de Gregorio López se identifican o confunden "los supuestos de infamia facti" con la infamia surgida de delito in haber recaído sentencia condenatoria. La razón podría estar en traducir "infamia ipso iure (o ipso facto)" como infamia de hecho. Pensamos que, de nuevo, incurre en contradicción al afirmar que desde las Partidas los casos de "infamia facti recogidos expresamente por la ley" no deberían considerarse supuestos "de infamia iuris", "aunque en realidad lo fueran", ya que la propia regulación, como él mismo advierte, le otorgaría carácter jurídico al atribuirle efectos jurídicos, sin que hubiese ninguna diferencia entre los casos de infamia factis de Partidas, 7, 6, 2 y los surgidos de la opinión pública. Masferrer Domingo, A., cit. (n. 25), pp. 277-282, 300 y 330.

${ }^{108}$ Partidas, 7, 6, 5, in fine.

109 Fororum regni aragonum, 4, 601. Fueros, Observancias, Actos de Corte, Usos y Costumbres con una reseña geográfica e histórica del Reino de Aragón ( $1^{\text {a }}$ trad. castellana de PARRAL y CRISTÓBAL, Luis, Zaragoza, Establecimiento Tipográfico de Mariano Salas, 1907), II, p. 385. 
rrado $^{110}$. Lo mismo se establecía en el Fuero de Jaca $a^{111}$ y en Navarra ${ }^{112}$. Se trataría de uno de los escasos ejemplos de pena infamante impuesta como pena principal y no accesoria de otra ${ }^{113}$. Otras marcas aparecen en el Fuero de Teruel, donde el hechicero era castigado con azotes y destierro después de haberle rapado el pelo en forma de cruz, si se demostraba su delito ${ }^{114}$. En el ámbito militar, cuando se encontraba lo robado (tras la sospecha del juez o de los alcaldes que escudriñaban las paradas), el ladrón se trasquilaba en cruz y se le cortaban las orejas ${ }^{115}$. Idéntica sanción se imponía al que se hacía escribir dos veces y se probaba ${ }^{116}$ o al que no escribía a todos sus hombres y se demostraba la mala fe ${ }^{117}$. Por su parte, el nombre del testigo falso era encartado para que se difundiese la infamia de su falsedad, además de pagar el doble de la demanda por la que había confirmado o jurado en falso y ser incapacitado para testificar para siempre ${ }^{118}$.

Sin duda, "el apogeo de las penas infamantes" tuvo lugar con la Inquisición con sanciones como "la decalvación y el afeitado, la soga, el sambenito y los ves-

110 Fueros de Borja y Zaragoza, 87, ed. de Morales Gómez, J. J. y Pedraza García, M. J. (Zaragoza, Anubar Ediciones, 1986); Recopilación de Fueros de Aragón, 87. Ramos Loscertales, J. M., en $A H D E ., 2$ (1925), p. 511. Para Alejandre, la decalvación parcial y las marcas en la frente eran "penas de tipo físico y a la vez infamantes". La decalvación era infamante porque el autor del delito de falsedad quedaba expuesto "a la vergüenza pública", siendo "la forma de prevenir a todos contra el reo, al anunciar públicamente la naturaleza de su delito". Sin embargo, interpreta la decalvación como el simple rapado sin más daños, por cuanto afirma la índole temporal de la medida punitiva. Respecto a la marca, le atribuye un doble carácter, r e a l, con el fin de "demostrar perpetuamente" "la condición de falso testigo" y s i m b ó l i c o por la forma de ejecutar la pena, es decir, se relaciona el instrumento utilizado (el badajo de la campana que produce el sonido) con la difusión de la acción delictiva y de la infamia del delincuente, lo que se deduce de la frase sicut vox campane auditur per diversa loca, ita iniuria et infamia eorum nota sit ubique gentibus. Alejandre García, J.A., cit. (n. 62), p. 89.

111 Fuero de Jaca, 236 (redacción A, Madrid, Biblioteca Nacional, 17801); Fuero de Jaca, 257 (redacción C, Madrid, Biblioteca Nacional, 13271); Fuero de Jaca, 256 (redacción D, Barcelona, Biblioteca de Catalunya, 1015); Fuero de Jaca, 271 (redacción E, Madrid, Biblioteca de Palacio, 943). El que alguna vez cometió falso testimonio (junto a los homicidas, ladrones y otros delincuentes) quedaba incapacitado para siempre para actuar como testigo. Fuero de Jaca, 254, 259 y 260 (redacción C); Fuero de Jaca 253, 258 y 259 (redacción D); Fuero de Jaca, 268, 273 y 274 (redacción E). Además, el perjuro era expulsado de la comunidad. Fuero de Jaca, 273 (redacción C); Fuero de Jaca, 272 (redacción D); Fuero de Jaca, 289 (redacción E). Seguimos la ed. crítica de Molho, Mauricio, El Fuero de Jaca, (Zaragoza, CSIC), 1964.

${ }^{112}$ Fuero General de Navarra, 215 (serie A) o 403 (serie B). Hemos consultado la edición de Utrilla Utrilla, Juan, El Fuero General de Navarra. Estudio y edición de las redacciones protosistemáticas (Series A y B) (Pamplona, Institución Príncipe de Viana, 1987), 2 vols. Asimismo, se disponía que los homicidas, ladrones manifiestos y falsos testigos, entre otros, no podían nunca testificar. Fuero General de Navarra, 252 y 552 (serie A) o 395 (serie B).

113 Es opinión de LaLinde Abadía, Jesús, Iniciación, cit. (n. 20), p. 657, de la $2^{\text {a }}$ ed.

114 Fuero de Teruel, 380, ed. crítica con introducción y traducción de CASTAÑÉ LLINÁs, José

(2a ed., Teruel, Ayuntamiento de Teruel, 1991). Por su parte, la mujer hechicera era quemada.

115 Fuero de Teruel, 430.

116 Fuero de Teruel, 431.

117 Fuero de Teruel, 432.

118 Fuero de Teruel, 511. 
tidos penitenciales"119. De hecho, el hereje y sus descendientes eran castigados con la infamia (que también se aplicaba a otros delitos relacionados como usura, bigamia, magia o hechicería) tanto por el derecho canónico como secular, y el sambenito suponía "el signo visible de la infamia" ${ }^{120}$.

\section{Evolución de la pena de marca en la Edad Moderna y abolición}

A principios de la Edad Moderna, los jueces seguían imponiendo las sanciones "aflictivas y afrentosas de mutilación, azotes o impresión de marca perpetua", aunque no en el rostro desde la prohibición de las Partidas ${ }^{121}$. Con carácter general, las penas corporales fueron abolidas por Carlos I, en virtud de una Pragmática de 31 de enero de 1530, así como por las de 16 de mayo de 1534 y 23 de febrero de 1535, y reemplazadas por el servicio en las galeras, cuya duración no podía ser inferior a dos años y dependía del delito cometido ${ }^{122}$. Son de relevancia por su utilidad práctica, las marcas que, desde 1564, se aplicaban a los ladrones "condenados a azotes o destierro en Cataluña", a los que se les señalaba la espalda "con las armas de la ciudad o villa" ${ }^{123}$. En una Pragmática de 3 de mayo de 1566, Felipe II sancionó el falso testimonio en proceso civil, con la pena de quitar los dientes, que podía ser conmutada por vergüenza pública y diez años de galeras y en causa criminal (que no fuese en caso de muerte), con vergüenza pública y

119 Lalinde Abadía, J., Iniciación, cit. (n. 20), p. 657, de la $2^{\text {a }}$ ed.. Sobre el sadismo en la ejecución de las penas corporales por parte del brazo secular y los rituales a los que se sometía al reo con claro efecto infamante, ver LALinde AbAdía, J., Las culturas, cit. (n. 2), II, pp. 830831. En cuanto al sambenito y al uso de la indumentaria como distintivo infamante, véase LALINDE ABADÍA, J., La indumentaria como simbolo de discriminación jurídico-social, en AHDE., 53 (1983), pp. 595-600. Cfr. TomÁs y VALIENTE, F., El derecho penal de la monarquía absoluta (siglos XVI-XVII-XVIII) (Madrid, Tecnos, 1992), p. 368 y Escudero LóPEZ, J. A., Estudios sobre la Inquisición (Madrid, Marcial Pons, 2005), pp. 33-34.

${ }^{120}$ Masferrer Domingo, Aniceto, cit. (n. 25), pp. 350 y 360. Cataloga el sambenito como pena corporal y afirma que su imposición era "muchísimo más humillante” y desgarradora "para la propia fama y reputación que otras penas corporales", irrigando tanto infamia de hecho como de derecho (pp. 360-363) (lo cual podría también predicarse de la marca por sus consecuencias jurídicas). En base al concepto que hemos defendido, no compartimos la consideración del sambenito como pena corporal, ya que no causaba ningún daño físico en el cuerpo del delincuente.

${ }^{121}$ Iglesias Rábade, Luis, Estudio, cit. (n. 24), p. 308. También en el derecho penal inglés de esta época, se mantuvo la marca con "hierro candente" "en partes visibles del cuerpo". Los vagabundos eran "marcados con una V" y los pendencieros "con una F (de Fraymaker) en el pecho" y si huían se sometían a "servidumbre perpetua" y se señalaban "con una S (Slave) en la cara o en la frente" (Statute of Vagabonds de 1547 de Eduardo VI). En la Poor Act de 1572 se incluía entre las sanciones "el señalamiento y la perforación de las orejas". En 1637, un delito de sedición fue castigado con la imposición de "las letras SL (seditious libeller) en ambas mejillas”. IgLesias RÁbAde, Luis, Las penas, cit. (n. 53), p. 136 y Estudio, cit. (n. 24), pp. 313, 314,317 y 323 y sobre la efectiva aplicación de las marcas por el Tribunal Penal Central de Londres, pp. 328 y 341-343.

${ }^{122}$ Nueva Recopilación, 8, 24, 4 y Novisima Recopilación, 12, 40, 1.

123 Lalinde Abadía, Jesús, Iniciación, cit. (n. 20), p. 656, de la 2a ed. y Las culturas, cit. (n. 2), II, p. 830. 
galeras a perpetuidad, haciendo extensiva la sanción a los inductores ${ }^{124}$, aunque hubiese perdón de parte ${ }^{125}$.

A medida que avanza la Edad Moderna, los castigos corporales desaparecen de forma progresiva, pero no por completo; de modo que, en pleno siglo XVII, se seguían imponiendo, aunque fuese de manera esporádica, y si las mutilaciones apenas se aplicaban, no se podía decir lo mismo de las marcas ${ }^{126}$. Ya en el siglo XVIII, la pena de marca casi no se contemplaba ni en las normas ni en la práctica judicial. Tan solo aparecía con carácter r e s i d u a l, castigándose "el robo con violencia y fuerza en personas y/o cosas o utilizando llave falsa, ganzúa u otro instrumento", con doscientos azotes y diez años en galeras para los plebeyos y la marca en la espalda con un hierro candente de la "letra L de ladrón" (aunque la pena capital se seguía aplicando "para los convictos de robo domiciliario con fuerza en las cosas”). La referida marca no tenía un fin infamante, sino que servía para probar la "reincidencia en el caso de ser posteriormente detenido por el mismo delito" 127 . Carlos III, en virtud de una Pragmática de 19 de septiembre 1783, estableció que todos los gitanos que no dejasen su lengua, traje y método de vida vagante fueran marcados en la espalda, con un pequeño hierro ardiente, que se tendrá dispuesto en la cabeza de partido, con las armas de Castilla ${ }^{128}$.

El pensamiento de la Ilustración se opuso con carácter general a las penas

${ }^{124}$ Nueva Recopilación, 8, 24, 6 y 8, 17, 7 y Novísima Recopilación, 12, 40, 3 y 12, 6, 5. Sainz Guerra considera que esta penalidad más leve fue debida a la dificultad de aplicar el talión y a la "necesidad imperiosa de galeotes en la flota". Felipe III reiteró estas normas en las Cortes de Madrid de 1602, publicándolas en 1610, probablemente porque subsistían las necesidades. Sainz Guerra, Juan, cit. (n. 1), pp. 599-600. Según Alejandre, la amputación de dientes no se aplicaba con frecuencia. Refiere las discrepancias doctrinales sobre su "contenido exacto" que para algunos consistía en la extracción de un solo diente y para otros, de la quinta parte de las piezas dentales o su totalidad y estas "dudas revelan que la ejecución de la pena era poco conocida”, aunque, en cualquier caso, desde 1566 debía conmutarse por la vergüenza pública y el servicio en galeras. Alejandre García, J. A., cit. (n. 62), pp. 115-116. A pesar de todo, hay ejemplos de la imposición de marcas en 1570. Redondo, Augustin, cit. (n. 15), pp. 193-194.

125 Nueva Recopilación, 8, 24, 10 y Novísima Recopilación, 12, 40, 4.

126 Redondo, Augustin, cit. (n. 15), pp. 186-187 y 198-199. Era frecuente señalar a los esclavos con un hierro candente, con la letra $S$ en una mejilla y con un clavo en la otra y, a veces, con el nombre de su dueño (pp. 194-195). En otras ocasiones, las ofensas se vengaban marcando con un cuchillo en la cara como signo de infamia (pp. 196-197).

127 Iglesias Rábade, Luis, Estudio, cit. (n. 24), pp. 334 y 341 . Véase Redondo, Augustin, cit. (n. 15), p. 191 y SALdAÑa García-Rubio, Quintiliano, El derecho penal de la Revolución (adiciones al Tratado de derecho penal de von LiszT, Franz, 3a ed., Madrid, Reus, c. 1930), I, p. 422. Tomás y Valiente no refiere la marca entre las penas recogidas en las normas con mayor frecuencia, aunque sí alude a la vergüenza pública. Tomás y VALIENTE, Francisco, cit. (n. 119), pp. 381 y 386-387. Sobre la repercusión en terceros de las penas infamantes, consultar pp. 394-395. Tampoco menciona la marca CañIZAres Navarro, Juan B., Las penas infamantes en las fuentes jurídicas castellanas de finales del Antiguo Régimen; naturaleza y noción, en Glossae. European Journal of Legal History, 12 (2015), pp. 206-231.

128 Novísima Recopilación, 12, 16, 11. La Novísima Recopilación contenía disposiciones de gran severidad contra gitanos y vagos a los que se castigaba con azotes, mutilaciones, galeras e incluso la muerte. JiméNEZ DE AsúA, Luis, cit. (n. 1), I, p. 748. Cfr. GutiérREZ, José Marcos, cit. (n. 17), p. 118 . 
humillantes y crueles que habían caracterizado el derecho penal histórico. La codificación pondría fin de forma definitiva a las marcas junto a las penas corporales, salvo los trabajos forzados ${ }^{129}$. La marca no se recogía en el Código Penal español de 1822; sin embargo, recurría con frecuencia a la pena de infamia que sería suprimida por el Código Penal de $1848^{130}$.

\section{Conclusiones}

Una constante en el derecho penal histórico es la crueldad en la tipología punitiva y en su ejecución. Una de las penas utilizada con frecuencia en la historia, desde tiempos remotos, era la marca. Generalmente, consistía en la imposición de una señal indeleble en una parte visible del cuerpo del reo mediante un hierro candente, aunque también se podía trasquilar el cuero cabelludo, clavar la lengua... Esto permitía identificar al delincuente y conocer su reincidencia con una finalidad práctica. La marca constituye, sin lugar a dudas, una sanción penal, pero la doctrina no se muestra unánime a la hora de determinar su naturaleza jurídica como pena corporal o infamante. Consideramos que las penas corporales son las que tienen como fin principal ocasionar un daño en el cuerpo del delincuente sin llegar a provocar la muerte, viéndose afectada su integridad física. Por otra

129 SAINZ Guerra, Juan, cit. (n. 1), p. 296. A comienzos del siglo XIX, la marca no se utilizaba en España, ya que se pretendía que el delincuente que había cumplido su condena, recuperase su reputación, lo que no era posible si llevaba una marca como "señal indeleble de su criminalidad" y "sello perpetuo de su ignominia". Por este motivo, la humanidad y "el interés de la sociedad destierran de toda legislación esta perniciosa pena”. EsCRICHE, Joaquín, Marca, en Diccionario razonado de legislación civil, penal, comercial y forense (Valencia, 1838; reimp. Caracas, Imprenta de Valentín Espinal, 1840), p. 386 y Diccionario razonado de legislación y jurisprudencia. Nueva edición corregida notablemente, y aumentada con nuevos artículos, notas y adiciones sobre el derecho americano, por Don Juan Guim (Paris, Librería de Rosa, Bouret y Compañía, 1852), p. 1201. Recordemos que Lardizábal situaba la marca al nivel de las mutilaciones, advirtiendo que, aunque estaban en desuso "por una general y humana costumbre", era "conveniente abolirlas expresamente", subrogando en su lugar otras proporcionadas a los delitos y a las circunstancias, tal y como había hecho la Nueva Recopilación. De LardizÁbal y URibe, Manuel, cit. (n. 17), pp. 91-93]. García Goyena concluía que para castigar a las mujeres por el delito de bigamia no se podía recurrir a la marca en la frente prevista en Novísima Recopilación, 12, 28, 6 ni al destierro, porque ambas penas estaban derogadas. En la abolición de las mutilaciones entiende también incluidas las marcas que, en algunos casos, se mantuvo en Francia hasta la Ley de 28 de abril de 1832. GARCía GOYENA, Florencio, Código criminal español según las leyes y prácticas vigentes comentado y comparado con el penal de 1822, el francés y el inglés (Madrid, Librería de los señores viuda de Calleja e hijos, 1843), I, pp. 31 y 273-274. Sobre la evolución del derecho penal en España, desde las Cortes de Cádiz hasta nuestros días, ver Quintero Olivares, Gonzalo, Pequeña historia penal de España (Madrid, Iustel, 2017).

${ }_{130}$ Código Penal de 1848, art. 23: La ley no reconoce pena alguna infamante. No obstante, aunque eliminaba la pena jurídica de infamia recogía otras "de naturaleza análoga como la reprensión pública, la argolla y la degradación”, de forma que "la desaparición completa de las penas infamantes o humillantes no se produjo de modo repentino sino que fue el resultado de un proceso más lento y gradual”. MASFERRER DOMINGO, A., cit. (n. 25), p. 388 y La codificación del derecho penal en España. Tradición e influencias extranjeras: su contribución al proceso codificador, en Alvarado Planas, J. y Martorell Linares, M. (coords.), Historia del delito y del castigo en la Edad Contemporánea (Madrid, Dykinson, 2017), pp. 70-71, 84-85. 
parte, las penas infamantes serían aquellas cuyo objetivo básico era ocasionar la infamia del reo, repercutiendo en su honor y en su reputación en la sociedad y privándolo de derechos, como el derecho a testificar.

Para concretar la naturaleza jurídica de la marca hay que tener en cuenta de un lado, la finalidad última de la pena y de otro, los propios efectos de la sanción. Si el objetivo era causar un simple daño físico, en mayor o menor medida, en el cuerpo del delincuente, se situaría entre las penas corporales. Si por el contrario, se pretendía identificar al reo y al delito que había cometido (permitiendo conocer su reincidencia), afectando a su honor y reputación, con mayores o menores consecuencias jurídicas, se incluiría entre las penas infamantes.

La marca, en sentido estricto e históricamente considerada, no perseguía como castigo el daño físico (que, en muchas ocasiones, era muy leve) sino la infamia, pero no solo ante la opinión pública (infamia de hecho), sino que también tenía efectos jurídicos (infamia de derecho) llevando al reo a la pérdida de derechos cuyo ejercicio requería buena fama. Además, la infamia procedía de la imposición de la marca. Todo esto nos lleva a afirmar su naturaleza infamante y ello con independencia de que cualquier sanción, sobre todo las corporales, ocasionaban la mala fama del condenado, afectando a su consideración social e implicando una humillación para el mismo.

En el derecho visigodo, era frecuente la decalvatio cuya naturaleza ha sido cuestionada por la doctrina debido a la incertidumbre sobre su forma de ejecución que se evidencia en la propia terminología de los textos analizados. Mantenemos su naturaleza de pena infamante si consistía en un simple trasquilado o incluso si llevaba consigo otras lesiones menores como desollar la frente, y se trataría de una pena corporal si implicaba la extirpación del cuero cabelludo. No nos cabe duda de que tenía una finalidad infamante. En el Liber Iudiciorum, era muy frecuente su imposición junto a los azotes para castigar los delitos cometidos por siervos y por judíos, entre otros casos.

Escasas referencias a la marca encontramos en el derecho local catalán. En las Costums de Tortosa hay un título dedicado a la infamia, donde se incluye entre los infames a los marcados (croat). La marca se solía aplicar en la frente y se establecía de forma subsidiaria en caso de insolvencia, cuando la pena pecuniaria principal superaba los quince sueldos y no pasaba los treinta, junto con los azotes y la vergüenza pública, incrementándose la infamia con la c o $\mathrm{r}$ r i d a por la ciudad. En Valencia, los bígamos insolventes eran corridos por la localidad siendo azotados y trasquilados en cruz (tonsoretur).

La marca está presente en el derecho castellano en la forma de rasurado del cabello, por ejemplo, en el Fuero de Béjar o en los Fueros de Cáceres y Usagre. El falso testimonio se castigaba con la pérdida de los dientes en el Libro de los Fueros de Castilla, en el Fuero Real y en el Fuero de Ayala, mientras que en el Espéculo se imponía la marca en la cara con un hierro ardiente. En las Partidas, no hay referencia expresa a la marca en su tipología punitiva, pero sí se recogía la pena de infamia. Se prohibía señalar a alguno en la cara, aunque se establecía el marcado con hierro candente de la letra B en los labios para sancionar la reincidencia de los insolventes en la blasfemia. 
En Aragón, se penalizaba con la infamia la usura. El testigo falso era trasquilado en cruz y quemado en la frente con el badajo de una campana caliente, como pena principal, en los Fueros de Borja y Zaragoza y en el Fuero de Jaca, al igual que en Navarra. El rapado en cruz también estaba presente en el Fuero de Teruel en el ámbito militar y para castigar al hechicero.

El triunfo de las penas infamantes tuvo lugar con la Inquisición, donde también se imponía la decalvación y el afeitado. En la Edad Moderna se seguía utilizando la pena de marca, por ejemplo, para los ladrones y los gitanos aunque iría desapareciendo de forma progresiva, hasta su abolición definitiva con la codificación.

\section{BiBLIOGRAFÍA}

Alejandre García, Juan Antonio, El delito de falsedad testimonial en el derecho histórico español, en HID., 3 (1976), pp. 9-140.

Alejandre García, Juan Antonio, Falsedad documental y falsedad testimonial. Estudio histórico-jurídico de dos tipos delictivos (Madrid, Dykinson, 2012).

Alturo, J., Bellès, J., Font i Rius, J. M., García, Y. y Mundó, A. M., (eds.), Liber Iudicum Popularis. Ordenat pel jutge Bonsom de Barcelona (Generalitat de Catalunya, Departament de Justícia i Interior, Barcelona, 2003).

Alvarado Planas, Javier y Oliva Manso, Gonzalo, Los Fueros de Castilla. Estudios y edición crítica del Libro de los Fueros de Castilla, Fuero de los fijosdalgo y las Fazañas del Fuero de Castilla, Fuero Viejo de Castilla y demás colecciones de fueros y fazañas castellanas (Madrid, Centro de Estudios Políticos y Constitucionales, 2004).

Bellés i Sallent, J., con la colaboración de Alturo, J., Font i Rius, J. M., Mundó, A. M. y OlIVAr, A., Llibre dels judicis. Traducció catalana moderna del Liber iudiciorum (Generalitat de Catalunya, Departament de Justícia i Interior, Barcelona, 2008).

Camacho de los Ríos, Fermín, La infamia en el derecho romano (Alicante, Generalitat Valenciana, Conselleria de Cultura, Educació i Ciència-Instituto de Cultura "Juan Gil-Albert”, Diputación provincial de Alicante, 1997).

Cantera Burgos, Francisco, Fuero de Miranda de Ebro (ed. crítica, versión y estudio, Madrid, CSIC, Instituto Francisco de Vitoria, 1945).

CaÑIZares Navarro, Juan B., Las penas infamantes en las postrimerías del Antiguo Régimen francés: tratamiento normativo y doctrinal, en Foro, Nueva época, 17 (2014), 1, pp. 101-137.

Cañizares Navarro, Juan B., Las penas infamantes en las fuentes jurídicas castellanas de finales del Antiguo Régimen; naturaleza y noción, en Glossae. European Journal of Legal History, 12 (2015), pp. 206-231.

Castañé Llinás, José, El Fuero de Teruel (2a ed., Teruel, Ayuntamiento de Teruel, 1991).

De Lardizábal y Uribe, Manuel, Discurso sobre las penas, contraído a las leyes penales de España para facilitar su reforma (Madrid, Joachin Ibarra, Impresor de la Cámara de S. M., 1782, ed. con "Introducción” de Serrano Butragueño, Ignacio, Granada, Comares, 1997).

De TAPIA, Eugenio, Febrero Novisimo, o librería de jueces, abogados y escribanos, refundida, ordenada bajo nuevo método, y adicionada con un Tratado del juicio criminal, y algunos otros (Valencia, Imprenta de Ildefonso Mompié, 1829), VII.

De Ureña y Smenjaud, Rafael y Bonilla y San Martín, Adolfo, Fuero de Usagre (siglo 
XIII). Anotado con las variantes del de Cáceres (Madrid, Hijo de Reus Editores, 1907).

De Uriarte Lebario, Luis María, El Fuero de Ayala (Madrid, Imp. Hijos de M. G. Hernández, 1912; 2a edición, Álava, Diputación Foral de Álava, 1974).

Dualde Serrano, Manuel, Fori Antiqui Valentiae (Madrid-Valencia, CSIC, 19501967).

Dumont, Esteban, Tratados de legislación civily penal, obra extractada de los manuscritos del señor Jeremias Bentham (trad. castellana con comentarios de SALAS, Ramón, con arreglo a la segunda edición revista, corregida y aumentada, Madrid, Imprenta de D. Fermín Villalpando, 1822), III.

Escudero López, José Antonio, Estudios sobre la Inquisición (Madrid, Marcial Pons, 2005).

ESCRICHE, Joaquín, Diccionario razonado de legislación civil, penal, comercial y forense (Valencia, 1838; reimp. Caracas, Imprenta de Valentín Espinal, 1840).

ESCRICHE, Joaquín, Diccionario razonado de legislación y jurisprudencia. Nueva edición corregida notablemente, y aumentada con nuevos artículos, notas y adiciones sobre el derecho americano, por Don Juan Guim (Paris, Librería de Rosa, Bouret y Compañía, 1852).

Estrada Rius, Albert, L'ordenament jurídico-criminal en els Costums d'Orta", en VII Centenari dels Costums d'Orta (1296-1996). Actes de les Jornades d'Estudi (Orta, 25-27 octubre 1996) (Horta de Sant Joan, Ajuntament d'Horta de Sant Joan, 1997), pp. 283-304.

FERnÁNDEZ DE BuJÁn, A., Observaciones acerca de las nociones de ignominia e infamia en derecho romano, en Homenaje a Juan Berchmans Vallet de Goytisolo (Madrid, Junta de Decanos de los Colegios Notariales de España, Consejo General del Notariado, 1988), pp. 313-341.

FERNÁNDEZ EsPINAR, R., El falso testimonio judicial en el derecho español (Granada, Majfer, 2015).

Ferrer y Valls, Francisco, Principios de legislación y de codificación extractados de la obra del filósofo inglés Jeremias Bentham (Madrid, Imprenta de Tomas Jordan, 1834), III.

Fueros, Observancias, Actos de Corte, Usos y Costumbres con una reseña geográfica e histórica del Reino de Aragón ( $1^{\text {a }}$ traducción castellana de PARRAL y CRISTÓBAL, Luis, Zaragoza, Establecimiento Tipográfico de Mariano Salas, 1907), II.

GarCía Goyena, Florencio, Código criminal español según las leyes y prácticas vigentes comentado y comparado con el penal de 1822, el francés y el inglés (Madrid, Librería de los señores viuda de Calleja e hijos, 1843), I.

García Goyena, Florencio y Aguirre, Joaquín, Febrero, o librería de jueces, abogados y escribanos, comprensiva de los Códigos civil, penal y administrativo, tanto en la parte teórica como en la práctica con arreglo en un todo a la legislación hoy vigente... (2a ed. corregida y anotada por los doctores AguirRe, Joaquín y Montalbán, Manuel, Madrid, Imprenta y Librería de Don Ignacio Boix, 1845), III.

Gibert y SÁnCHEZ de la Vega, Rafael, Recensión de Bicentenario de la muerte de don José Febrero. Acto de homenaje y catálogo de la exposición bibliográfica, Consejo General del Notariado, Madrid, 1991, en AHDE., 68 (1998), pp. 593-596.

Greenidge, Abel Hendy Jones, Infamia. Its place in roman public and private law (Oxford, 1874, reimpresión, Scientia Verlag Aalen, 1977).

Gudín Rodríguez-Magariños, Faustino y Nistal Burón, Javier, La historia de las penas. "De Hammurabi a la cárcel electrónica" (Valencia, Tirant lo Blanch, 2015). 
GutiÉRrez, José Marcos, Febrero reformado y anotado, o Librería de escribanos que compuso don Joseph Febrero Escribano Real y del Colegio de la corte, y ha reformado en su lenguaje, estilo, método y muchas de sus doctrinas ilustrándola, y enriqueciéndola con varias notas y adiciones para que se han tenido presentes las Reales Órdenes modernas (2a ed., Madrid, Imprenta de Villalando, 1802), 5 vols.

Gutiérrez, José Marcos, Discurso sobre los delitos y las penas, en Práctica criminal de España (Madrid, 1804; 2a ed., Madrid, Imprenta de D. Fermín Villalpando, 1819), III.

Gutiérrez Cuadrado, Juan, Fuero de Béjar (Salamanca, Secretariado de Publicaciones e Intercambio Científico, Universidad de Salamanca, 1974).

Gutiérrez Fernández, B., Examen histórico del derecho penal (Madrid, Antonio Peñuelas, 1866).

IGLESIAS RÁBADE, Luis, Estudio comparado de las penas corporales en el derecho hispánico e inglés en la Edad Moderna, en AHDE., 86 (2016), pp. 297-349.

- Las penas corporales en el derecho hispánico e inglés en la Edad Media. Estudio comparado, en REHJ., 38 (2016), pp. 123-147.

- El falso testimonio judicial en el derecho hispánico y anglo-sajón en el Medievo. Estudio comparado, en En la España medieval, 40 (2017), pp. 67-110.

Jiménez de Asúa, Luis, Tratado de derecho penal (4a ed., Buenos Aires, Losada, 1964), I.

Lalinde Abadía, Jesús, Iniciación histórica al derecho español (Barcelona-Caracas, México, $1^{\text {a }}$ ed., 1970; $2^{\text {a }}$ ed. actualizada, 1978).

- La indumentaria como simbolo de discriminación jurídico-social', en AHDE., 53 (1983), pp. 583-601.

- Las culturas represivas de la humanidad (H. 1945) (Zaragoza, Universidad de Zaragoza, 1992), 2 volúmenes.

Lara Peinado, Federico, Código de Hammurabi (Madrid, Editora Nacional, 1982; $4^{\mathrm{a}}$ ed., Madrid, Tecnos, 2008).

Los Códigos españoles concordados y anotados (Madrid, Imprenta de la Publicidad a cargo de M. Rivadeneyra, 1847), I.

Loscertales de Valdeavellano, Pilar, Costumbres de Lérida (Barcelona, Universidad de Barcelona, 1946).

Masferrer Domingo, Aniceto, La pena de infamia en las Costumbres de Horta, en VII Centenari dels Costums d'Orta (1296-1996). Actes de les Jornades d'Estudi (Orta, 25-27 octubre 1996) (Horta de Sant Joan, Ajuntament d'Horta de Sant Joan, 1997), pp. 329-342.

- La pena de infamia en el derecho histórico español. Contribución al estudio de la tradición penal española en el marco del ius commune (Madrid, Dykinson, 2001).

- La dimensión ejemplarizante del derecho penal municipal catalán en el marco de la tradición jurídica europea. Algunas reflexiones iushistórico-penales de carácter metodológico, en AHDE., 71 (2001), pp. 439-471.

- La codificación del derecho penal en España. Tradición e influencias extranjeras: su contribución al proceso codificador, en Alvarado Planas, J. y Martorell Linares, M. (coords.), Historia del delito y del castigo en la Edad Contemporánea (Madrid, Dykinson, 2017), pp. 59-95.

Massip i Fonollosa, Jesús, Costums de Tortosa (colllaboració de Duarte, C. y Massip, À. y "pròleg” de Font i Rius, Josep M., Barcelona, Fundació Noguera, 1996).

Minguijón, Salvador, Historia del derecho español (Barcelona-Buenos Aires, Labor, 1926), I. 
MolHo, Mauricio, El Fuero de Jaca (Zaragoza, CSIC), 1964.

Mommsen, Theodor, Römisches Strafrecht (trad. castellana de Dorado Montero, Pedro, Bogotá, Temis, 1991; Pamplona, 1999).

Morales Gómez, Juan José y Pedraza García, Manuel José, Fueros de Borja y Zaragoza (ed. crítica e índices, Zaragoza, Anubar Ediciones, 1986).

Muñoz y Romero, Tomás, Colección de Fueros Municipales y Cartas Pueblas de los reinos de Castilla, León, Corona de Aragón y Navarra (Madrid, Imprenta de Don José María Alonso, 1847; reedición anastática, Madrid, Lope de Vega, 1972).

Oliver, Bienvenido, Historia del derecho en Cataluña, Mallorca y Valencia. Código de las Costumbres de Tortosa (Madrid, Imprenta de Miguel Ginesta, 1876, 1879 y 1881), I, III y IV.

Orlandis Rovira, José, Las consecuencias del delito en el derecho de la Alta Edad Media, en $A H D E$., 18 (1947), pp. 61-165.

Ourliac, Paul y Pilles, Monique, Les Fors Anciens de Béarn (Paris, CRNS éditions, 1990).

Planas Rosselló, Antonio, Los delitos contra el matrimonio y la moral sexual en el derecho histórico de Mallorca, en Bolletí de la Societat Arqueològica Lul.liana, 56 (2000), pp. 45-64.

Planas Rossello, Antonio, El derecho penal histórico de Mallorca (siglos XIII-XVIII) (Palma, Universitat de les Illes Balears, 2001).

Platón, Las Leyes, Libro IX (Obras Completas, ed. de De AzCárate, Patricio, Madrid, 1872), X.

Puyol Alonso, Julio, Orígenes del Reino de León y de sus instituciones politicas (León, Editorial Nebrija, 1979).

Quintero Olivares, Gonzalo, Pequeña historia penal de España (Madrid, Iustel, 2017).

Ramos Loscertales, José María, Textos para el estudio del derecho aragonés en la Edad Media: Recopilación de Fueros de Aragón, en AHDE., 2 (1925), pp. 491-522.

Redondo, A., Mutilations et marques corporelles d'infamie dans la Castille du XVIe siècle, en Le corps dans la société espagnole des XVI et XVII siècles (Paris, Publications de la Sorbonne, 1990), pp. 185-199.

SAinz Guerra, Juan, La evolución del derecho penal en España (Jaén, Universidad de Jaén, 2004).

Saldaña García-Rubio, Quintiliano, El derecho penal de la Revolución (adiciones al Tratado de derecho penal de von LiszT, Franz, $3^{\mathrm{a}}$ ed., Madrid, Reus, c. 1930), I.

Serrano i Daura, Josep, Els Costums de la batllia de Miravet (Tarragona, Consell Comarcal de la Terra Alta, 1999).

Tilander, Gunnar, O uso de rapar a cabeça aos delinquentes e aos loucos, en Leges Hispanicae Medii Aevi (Stockholm, 1959), VIII, pp. 17-22.

TOMÁs y Valiente, Francisco, El derecho penal de la monarquía absoluta (siglos XVIXVII-XVIII) (Madrid, Tecnos, 1992).

Utrilla Utrilla, Juan, El Fuero General de Navarra. Estudio y edición de las redacciones protosistemáticas (Series A y B) (Pamplona, Institución Príncipe de Viana, 1987), 2 vols.

Zambrana Moral, Patricia, Rasgos generales de la evolución histórica de la tipología de las penas corporales, en REHJ., 27 (Valparaíso 2005), pp. 197-229. 
